\title{
Review Article \\ Chemical Characteristics, Synthetic Methods, and Biological Potential of Quinazoline and Quinazolinone Derivatives
}

\author{
Mohammad Asif \\ Department of Pharmacy, GRD (PG) Institute of Management and Technology, Dehradun, Uttarakhand 248009, India \\ Correspondence should be addressed to Mohammad Asif; aasif321@gmail.com
}

Received 15 August 2014; Revised 11 September 2014; Accepted 16 September 2014; Published 13 November 2014

Academic Editor: Giulio Rastelli

Copyright (C) 2014 Mohammad Asif. This is an open access article distributed under the Creative Commons Attribution License, which permits unrestricted use, distribution, and reproduction in any medium, provided the original work is properly cited.

\begin{abstract}
The heterocyclic fused rings quinazoline and quinazolinone have drawn a huge consideration owing to their expanded applications in the field of pharmaceutical chemistry. Quinazoline and quinazolinone are reported for their diversified biological activities and compounds with different substitutions bring together to knowledge of a target with understanding of the molecule types that might interact with the target receptors. Quinazolines and quinazolinones are considered as an important chemical for the synthesis of various physiological significance and pharmacological utilized molecules. Quinazolines and quinazolinone are a large class of biologically active compounds that exhibited broad spectrum of biological activities such as anti-HIV, anticancer, antifungal, antibacterial, antimutagenic, anticoccidial, anticonvulsant, anti-inflammatory, antidepressant, antimalarial, antioxidant, antileukemic, and antileishmanial activities and other activities. Being considered as advantaged scaffold, the alteration is made with different substituent.
\end{abstract}

\section{Introduction}

Quinazolines and quinazolinones are classes of fused heterocycles that are of considerable interest because of the diverse range of their biological properties [1]. Many substituted quinazoline and quinazolinone derivatives possess a wide range of bioactivities such as antimalarial, anticancer, antimicrobial, antifungal, antiviral, antiprotozoan, anti-inflammatory, diuretic, muscle relaxant, antitubercular, antidepressant, anticonvulsant, acaricidal, weedicide, and many other biological activities. Quinazoline and quinazolinone compounds are also used in preparation of various functional materials for synthetic chemistry and also present in various drugs molecules (Figure 1). This review is an attempt to expand the huge potentiality and focused on the various biological activities of quinazolines and quinazolinones [2].

Quinazolinones will be classified into the following five categories, based on the substitution patterns of the ring system [3]. These are 2-substituted-4(3H)-quinazolinones, 3 -substituted-4(3H)-quinazolinones, 4-substituted-quinazolines, 2,3-disubstituted-4(3H)-quinazolinones, and 2,4disubstituted-4(3H)-quinazolinones. Depending upon the position of the keto or oxo group, these compounds may be classified into three types [4]. Out of the three $(2(1 \mathrm{H})$ quinazolinones, $4(3 \mathrm{H})$ quinazolinones and $2,4(1 \mathrm{H}, 3 \mathrm{H})$ quinazolinedione) quinazolinone structures, $4(3 \mathrm{H})$-quinazolinones are most prevalent, either as intermediates or as natural products in many proposed biosynthetic pathways (see Scheme 1).

This is partly due to the structure being derived from the anthranilates (anthranilic acid or various esters, isatoic anhydride, anthranilamide, and anthranilonitrile) while the $2(1 \mathrm{H})$-quinazolinone is predominantly a product of anthranilonitrile or benzamides with nitriles [4].

\section{History}

In 1869 Griess prepared the first quinazoline derivative, 2-cyano-3,4-dihydro-4-oxoquinazoline, by the reaction of cyanogens with anthranilic acid. The bicyclic product was called bicyanoamido benzoyl and used this name until 1885 [5]. The preparation of the quinazoline came many years later when Bischler and Lang obtained it by decarboxylation of the 2-carboxy derivative. A more satisfactory synthesis of quinazoline was subsequently devised by 

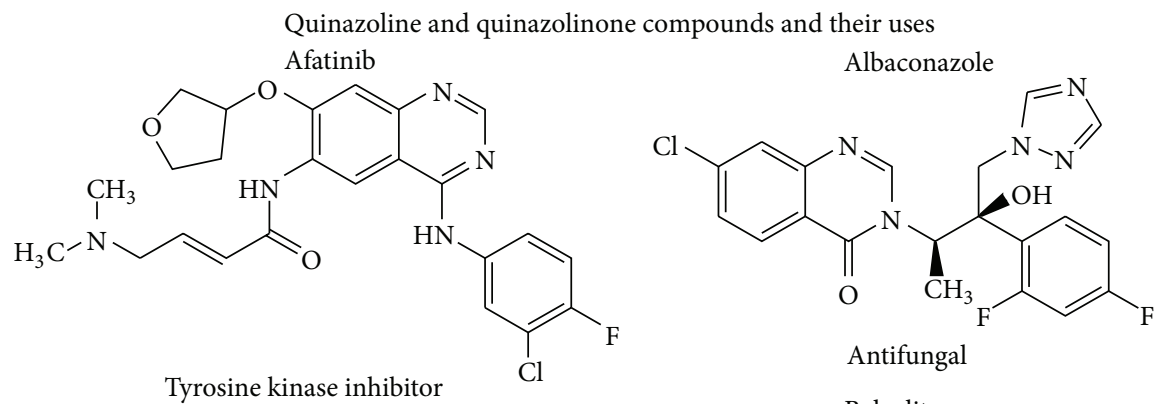

Antifungal<smiles>COc1cc2cnc(N(C)CCCNC(=O)C3CCCO3)nc2cc1OC</smiles>

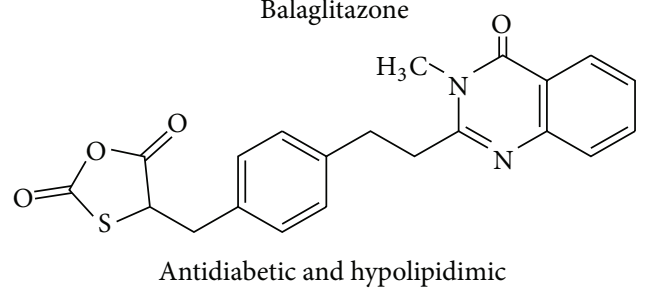

Antidiabetic and hypolipidimic<smiles>CCN(CCCOc1ccc2c(Cc3n[nH]cc3CC(=O)Nc3cccc(F)c3)nncc2c1)CCOP(O)(O)(O)O</smiles>
Cediranib

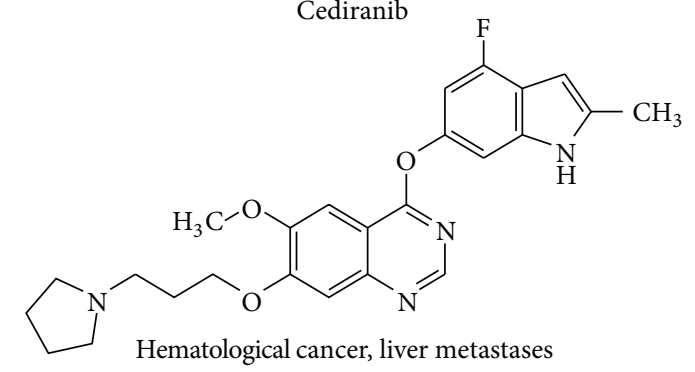
Hematological cancer, liver metastases<smiles>COc1cc2ncnc(Nc3ccc(F)c(Cl)c3)c2cc1NC(=O)/C=C/CN1CCCCC1</smiles>
Verubulin Anticancer<smiles>COc1ccc(N(C)c2nc(C)nc3ccccc23)cc1</smiles>

GS1101(CAL101)<smiles>CCC(c1ncnc2[nH]cnc12)c1nc2cccc(F)c2c(=O)n1-c1ccccc1</smiles>

Antihaematological cancer<smiles>Cc1ccc(C(=O)N(CCCN)[C@H](c2nc3cc(Cl)ccc3c(=O)n2Cc2ccccc2)C(C)C)cc1</smiles><smiles>COc1cccc(N2CCN(C3=Nc4c(F)cccc4[C@@H](CC(=O)O)N3c3cc(C(F)(F)F)ccc3OC)CC2)c1</smiles><smiles>CNC(=O)C1=CC(C)C2=C1C(C)(C)Cc1cnc(Nc3ccc(N4CCN(C)CC4)cc3)nc12</smiles>

Anticancer

(a)

FIgure 1: Continued. 


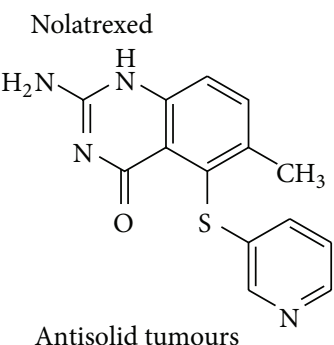

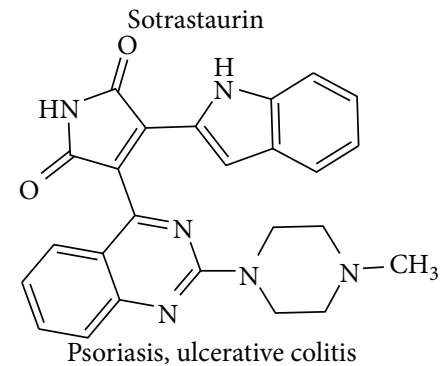<smiles>COc1cc2c(N3CCN(C(=O)Nc4ccc(CC(C)C)cc4)CC3)ncnc2cc1OCCCN1CCCCC1</smiles><smiles>Clc1cc(Nc2ncnc3ccc(NC4=NCCO4)cc23)ccc1OCc1nccs1</smiles>

Anticancer drug<smiles>CNc1cc2[nH]c(=O)n(-c3ccc(NC(=O)CS(=O)(=O)c4ccc(Cl)s4)cc3)c(=O)c2cc1F</smiles>

(b)

FIGURE 1: Some marketed available drugs contain quinazoline and quinazolinone moiety [2].<smiles>c1ccc2ncncc2c1</smiles><smiles>O=c1ncc2ccccc2[nH]1</smiles>

Quinazoline

2(1H)quinazolinone<smiles>O=c1[nH]cnc2ccccc12</smiles>

4(3H)quinazolinone<smiles>O=c1[nH]c(=O)c2ccccc2[nH]1</smiles>

$4(1 \mathrm{H}, 3 \mathrm{H})$ quinazolinedione

SCHEMe 1

Gabriel in 1903. The name was proposed by Widdege. Other names such as phenmiazine, benzyleneamidine, benzo-1,3diazine, 5,6-benzopyrimidine, and 1,3-diazanapthaline have occasionally been used. The presence of a fused benzene ring alters the properties of the pyrimidine ring considerably. The two nitrogen atoms are not equivalent, and the marked polarization of the 3,4-double bond is reflected in the reactions of quinazoline. The properties of substitute's quinazolines depend largely on (a) the nature of the substituents, (b) whether they are in the pyrimidine ring or in the benzene ring, and (c) whether or not complete conjugation is present in the pyrimidine ring [6-8] (see Scheme 2).

\section{Chemical Properties of Quinazolines}

The chemistry of quinazoline was reviewed by Williamson in 1957 and then by Lindquist in 1959 and brought up to date by Armarego in 1963.

Quinazolines is stable in cold dilute acid and alkaline solutions, but it is destroyed when these solutions are boiled. O-Aminobenzaldehyde, ammonia, and formic acid are formed when quinazoline is boiled with hydrochloric acid.

3.1. Hydrolysis, Oxidation, and Reduction. Oxidation of quinazoline in dilute aqueous acid with two equivalents of 
<smiles>N#CC1N=C2C=CC=CC2C(=O)N1</smiles>

2-Cyano-3,4-dihydro-4-oxoquinazoline

SCHEMe 2

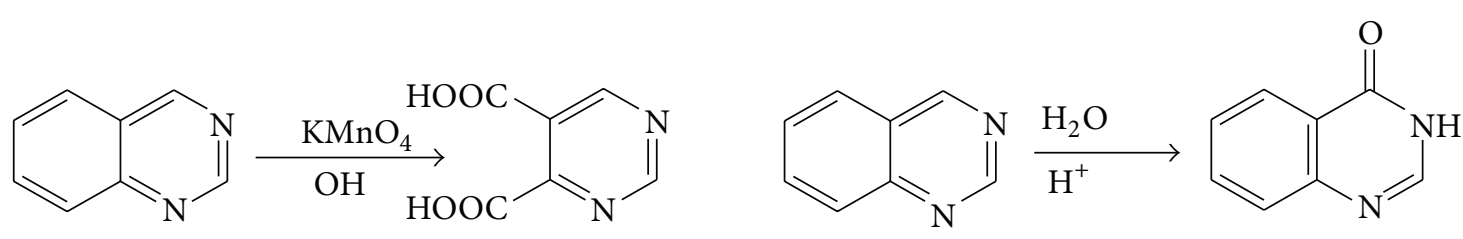

SCHEME 3<smiles>c1ccc2c(c1)CNCN2</smiles><smiles>c1ccc2ncncc2c1</smiles><smiles></smiles>

[H]<smiles>C1=Nc2ccccc2CN1</smiles>

SCHEMe 4<smiles>Nc1ncnc2ccccc12</smiles><smiles>NNc1ncnc2ccccc12</smiles>

SCHEMe 5

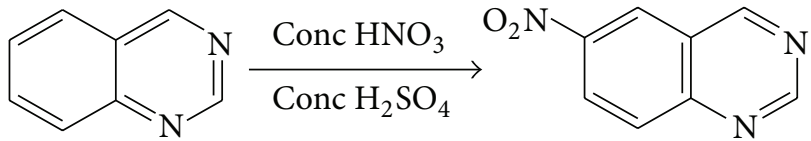

SCHEME 6

hydrogen peroxide at room temperature gave 3,4-dihydro4-oxo quinazoline. In alkaline medium, the anhydrous neutral species of quinazoline were predominantly undergo oxidation with $\mathrm{KMnO}_{4}$ and yielded 3,4-dihydro-6 4-oxo quinazoline.

3.1.1. Oxidation. Catalytic hydrogenation of quinazoline stopped after the absorption of one molecule of hydrogen and gave 3,4-dihydro quinazoline (see Scheme 3).

3.1.2. Reduction. Reduction with sodium amalgam gave 1,2,3,4-tetrahydroquinazoline. Lithium aluminum hydride and sodium borohydride gave 3,4-dihydro and 1,2,3,4tetrahydroquinazoline (see Scheme 4).
3.2. Nucleophilic and Electrophilic Substitution Reactions. The two known nucleophilic substitution reactions of quinazoline are sodamide and hydrazine most probably proceed via the intermediate addition products, and gave 4-amino and 4hydrazine quinazoline (see Scheme 5).

3.2.1. Electrophilic Substitution Reaction of Quinazoline. Nitration is the only known electrophilic substitution reaction of quinazoline. The expected order of reactivity is at positions $8>6>5>7>4>2$. Quinazoline gives 6nitroquinazoline with fuming nitric acid in concentrated $\mathrm{H}_{2} \mathrm{SO}_{4}$. No oxidation of the heterocyclic ring can occur under these conditions because the hydrated cation is not present (see Scheme 6). 


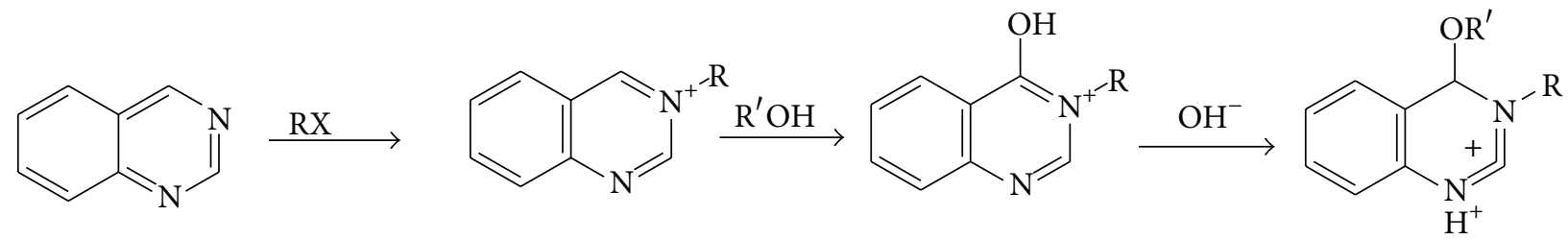

SCHEME 7

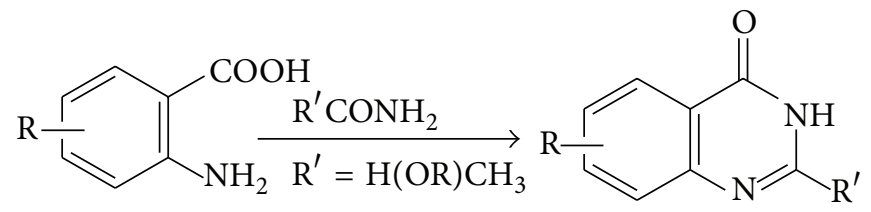

SCHEMe 8

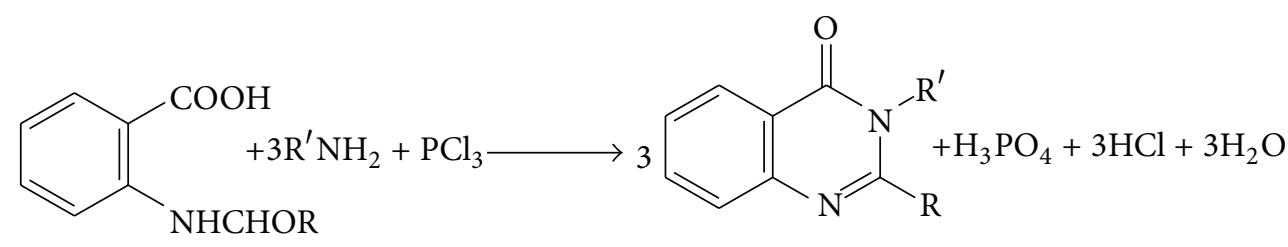

SCHEMe 9<smiles>[R]NC(=O)c1ccc(N)cc1N</smiles>

SCHEMe 10

3.3. Alkylation Reactions. Alkylation of quinazoline takes place on $\mathrm{N}$ atom, 3-methyl, 3-ethyl-3-alkyl, and 3-benzylquinazolinium salts that readily take up a molecule of alcohol to form the corresponding 4-alkoxy-3-alkyl-3,4dihydro quinazolinium salts. These salts gave the pseudo bases, 3-alkyl-3,4-dihydro-4-hydroxy quinazolines on treatment with strong alkali (see Scheme 7).

3.4. Addition Reactions. Quinazoline is highly reactive towards anionic reagents which attack on position 4. Sodium bisulphate, hydrogen cyanide, acetone, 2-butanone, acetophenone, and cyclohexanone add across the 3,4-double bond of quinazoline. Methyl, ethyl, isopropyl, benzyl, t-butyl, and phenyl magnesium halides and phenyl lithium also add across the 3,4-double bond to give the corresponding 4substituted 3,4-dihydroquinazolines.

\section{Synthesis of Quinazoline Compounds}

Various methods were reported for the synthesis of oxoquinazolines.
4.1. Niementowski's Synthesis. Compound 3 or 4-substituted anthranilic acid when reacted with formamide at $125-130^{\circ} \mathrm{C}$ gave 3,4-dihydro-4-oxoquinazoline (see Scheme 8).

4.2. Grimmel, Guinther, and Morgan's Synthesis. The o-amino benzoic acids, when heated with an amine together with phosphorous trichloride in toluene for two hours, gave 2,3disubstituted 3,4-dihydro-4-oxoquinazolines (see Scheme 9).

4.3. From Isatoic Anhydride. Isatoic anhydride was readily reacted with amines to dihydro-4-oxoquinazolines by refluxing ethyl orthoformate for 1-6 hrs without isolating the intermediate amides (see Scheme 10).

4.4. From 3,1,4-Benoxazones (Acylanthranils) and Amines. 3,1,4-Benoxazones react with amines to give 3,4-dihydro-4oxoquinazolines. Primary aliphatic amines and anilines react with 2-methyl-5-nitro-4-oxoquinazolines (see Scheme 11).

4.5. From Ethyl 2-Acetamido-5-nitrobenzoate. Ethyl 2acetamido-5-nitrobenzene and alcoholic ammonia when 
<smiles>[R]n1c(C)nc2cccc([N+](=O)[O-])c2c1=O</smiles>

SCHEME 11<smiles>[R]C(=O)Nc1ccccc1C(=O)Nc1ccccc1C(=O)NC([R])N</smiles>

SCHEME 12<smiles></smiles>

SCHEME 13<smiles>[R][X]1=C=CC(C(=O)O)=C(N)C1</smiles><smiles>[R][X]c1ccc2[nH]c(=O)[nH]c(=O)c2c1</smiles>

SCHEME 14

heated gave 3,4-dihydro-methyl-6-nitro-4-oxoquinazoline (see Scheme 12).

4.6. Sen and Ray's Synthesis. Boiling a solution of normal or isobutyrylanilides with urethane and phosphorous pentoxide in xylene gave 2-propyl and 2-isopropyl-3,4-dihydro-4oxoquinazolines (see Scheme 13).

\section{Methods for the Synthesis of Quinazoline and Quinazolinone Derivatives (Benzoylene Urea)}

Some methods were reported for the synthesis of quinazolines and quinazolinones are as follows.

5.1. From Anthranilic Acid and Urea. The fusion of anthranilic acid with urea gave 1,2,3,4-tetrahydro-2,4-dioxoquinazoline (see Scheme 14).
5.2. From O-Ureidobenzoic Acid. The o-ureidobenzoic acids are prepared from the corresponding anthranilic acid and potassium cyanate. The ureido acids are then easily cyclized to the respective 1,2,3,4-tetrahydro-2,4-dioxoquinazolines by heating with acid or alkali (see Scheme 15).

5.3. From O-Ethoxy Carbonylaminobenzoic Esters or Amides. When o-ethoxycarbonylamino benzamide and its 4-methyl derivatives are heated over their melting points, then they lose water and form 1,2,3,4-tetrahydro-2,4-dioxoquinazoline (see Scheme 16).

5.4. From Phthalic Acid Derivatives. The derivatives of phthalic acid used for the preparation of dioxoquinazoline necessitate rearrangement of the Hoffmann Curties or Lossan type. Reaction of phthalamide or phthalimide, N-methyl, and N-ethyl phthalimide with alkali hypobromite gives the 1,2,3,4-tetrehydro 2,4-dioxoquinazoline (see Scheme 17). 


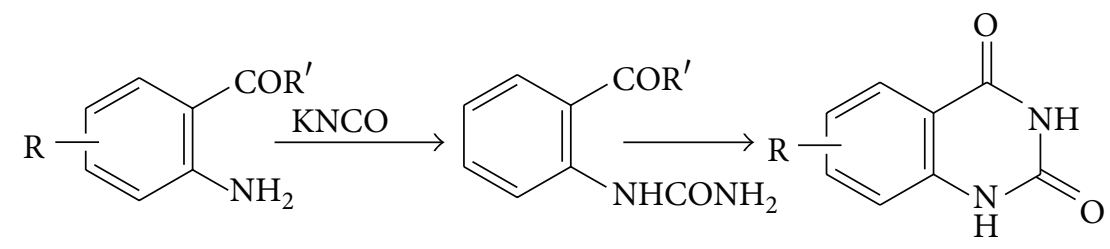

SCHEMe 15

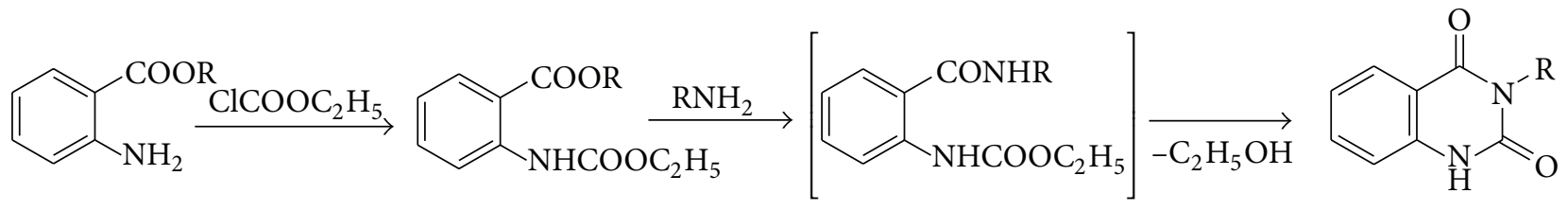

Scheme 16<smiles>[R]n1c(=O)[nH]c2ccccc2c1=O</smiles>

SCHEMe 17<smiles>[R]N=c1oc(=O)[nH]c2ccc(C(O)O)cc12</smiles>

SCHEME 18

5.5. From Isatins. $\alpha$-Isatin oxime rearranges to $1,2,3,4$ tetrahydro-2,4-dioxoquinazoline on heating with dilute sodium hydroxide; $\beta$-imino derivatives of isatin, on the other hand, require oxidation with hydrogen peroxide in alkaline solution in order to form the dioxoquinazoline (see Scheme 18).

5.6. From 2-Aminobenzylamine. The 2-aminobenzylamine reacts with butyrolactone which involves forming intermediate compound and further condensed with benzaldehyde to give 3-(2-chlorobenzylidene)-1,2,3,9-tetrahydropyrrolo-2quinazoline (see Scheme 19).

5.7. From 2-Azido-4-chlorobenzoic Acid. The 2-azido-4chlorobenzoic acid reacts with benzyl nitrile and formed 7-chloro-3-phenyl-[1, 2, 3] triazolo[1,5-a]quinazoline-5-one [9] (see Scheme 20).

Condensation of o-iodobenzaldehydes with amidine hydrochlorides under ligand-free copper catalyzed Ullmann
$\mathrm{N}$-arylation conditions afforded the corresponding quinazolines [10]. Treatment of benzoxazine with hydrazine hydrate in ethanol prepared 3-amino-2-phenyl quinazolin-4- $(3 \mathrm{H})$ one, which upon condensation with aldehydes gives the corresponding 3-arylidenoamino derivatives. Cyclization of these derivatives using mercaptosuccinic acid afforded 1,3thiazolidin-4-one ethanolic acid, which after esterfication with $\mathrm{N}$-hydroxyphthalimide or $\mathrm{N}$-hydroxysuccinamide via acid chlorides produced the respective ethanolic esters [11]. A series of quinoxalin-2(1H)-one-3-hydrazone derivatives were synthesized via condensation of 3-hydrazinoquinoxalin$2(1 \mathrm{H})$-one with the corresponding ketones under microwave irradiation and gave hydrazones in high yield in less reaction time compared to conventional method [12]. The (hydroxyimino)(2-phenyl(1,2,3,4-tetrahydroquinazolin2 -yl)) methane and (hydroxyimino) (2-(2-thienyl)(1,2,3,4tetrahydro quinazolin-2-yl)) methane were synthesized by the condensation of 2-(hydroxyimino)-1-phenylethan-1-one and 2-(hydroxyimino)-1-(2-thienyl) ethan-1-one with 2aminobenzylamine (2-ABA). Complexes of these ligands 
<smiles>NCc1ccccc1N</smiles>

SCHEME 19

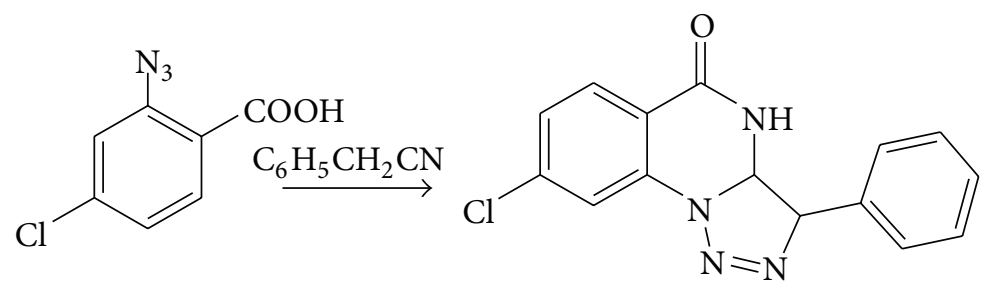

SCHEME 20<smiles>COc1ccc(-n2c(SCC(=O)c3ccc(Cl)cc3)nc3ccccc3c2=O)cc1</smiles><smiles>COc1ccc(C(=O)CSc2nc3ccccc3c(=O)n2-c2ccc(Cl)cc2)cc1</smiles>

SCHEMe 21

with $\mathrm{Co}^{3+}$ were prepared with a metal: ligand ratio of $1: 2$ [13]. The $[4+2]$ cycloaddition between 2,4-diphenylpyrimidine ortho-quinodimethane and dimethyl acetylenedicarboxylate leads to 2,4-diphenylquinazoline-6,7-dicarboxylate. 2,4Diphenylfuro [3,4-g]quinazoline-6,8-dione is also obtained by basic hydrolysis of compound, followed by the closure of the resulting diacid in acetic anhydride [14]. A series of triazoloquinazolinones and benzimidazoquinazolinones has been achieved under microwave irradiation by the reaction of aromatic aldehydes with 5-amino-1(H)-1,2,4triazole (or 2-aminobenzimidazole) and dimedone in DMF [15].

\section{Biological Importance of Quinazoline Derivatives}

The quinazoline and quinazolinone skeleton is frequently encountered in medicinal chemistry. The various substituted quinazolines and quinazolinones are having significant antihypertensive, antineoplastic, antidepressant, and antipsychotic activities whereas some derivatives of quinazoline and quinazolinones are found to be effective agents such as analgesic, antipsychotic, antiarrhythmic, sedative hypnotics, antibacterial, anti-inflammatory, antifungal, antimalarial, anticonvulsant, anticoccidial, anti-Parkinsonism, cancer and other activities [6-8].

6.1. Quinazolinones as Anticancer Activity. Some new 3substituted quinazolin-4(3H)-ones and 3,4-dihydro-quinazolin-2(1H)-one derivatives are reported that compounds 2-[2-(4-chlorophenyl)-2-oxo-ethylthio]-3-(4-methoxyphenyl)quinazolin-4(3H) one (1) and 3-(4-chlorophenyl)-2-[2(4-methoxyphenyl)-2-oxo-ethylthio]quinazolin-4(3H)-one (2) as broad-spectrum antitumors show effectiveness toward numerous cell lines that belong to different tumor subpanels [16] (see Scheme 21).

A series of novel quinazoline derivatives (3-6) containing thiosemicarbazide moiety and evaluate their biological activity as antitumor agents [17]. The therapeutically important candidates are shown in (see Scheme 22).

A series of phenyl $\mathrm{N}$-mustard-quinazoline derivatives (7a-d) were evaluated for their antitumor activity [18] (see Scheme 23).

A series of few 4,6 di-substituted-(diaphenylamino)quinazolines derivatives $(\mathbf{8} \mathbf{a}-\mathbf{b})$ were evaluated for antitumor activity was considered as potent EGFR inhibitors [19]. A series of quinazoline derivatives $(\mathbf{9 a}-\mathbf{c})$ were 


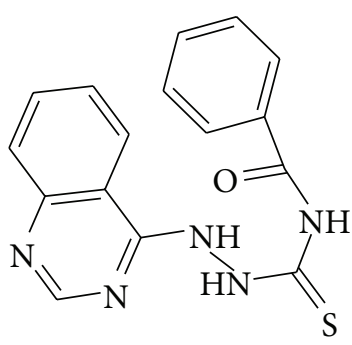

3<smiles>O=C(NC(=S)NNc1ncnc2ccccc12)c1ccc(F)cc1</smiles>

4<smiles>O=C(NC(=S)NNc1ncnc2ccccc12)c1ccccc1F</smiles>

5<smiles>COc1cc2ncnc(NNC(=S)NC(=O)c3ccc(Cl)cc3)c2cc1OC</smiles>

6

SCHEME 22<smiles>[R]c1cc(Nc2ncnc3ccc(NC(=O)Nc4ccc(N(CCCl)CCCl)cc4)cc23)c([R])c([R1])c1[R]</smiles>

$\begin{array}{ccccc}\text { Compd } & \mathrm{R} & \mathrm{R}_{1} & \mathrm{R}_{2} & \mathrm{R}_{3} \\ 7 \mathbf{a} & -\mathrm{H} & -\mathrm{OCH}_{3} & -\mathrm{OCH}_{3} & -\mathrm{OCH}_{3} \\ 7 \mathbf{b} & \mathrm{F} & \mathrm{Cl} & \mathrm{H} & \mathrm{H} \\ \mathbf{7 c} & \mathrm{H} & \mathrm{Cl} & \mathrm{F} & \mathrm{H} \\ \mathbf{7 d} & \mathrm{H} & \mathrm{C} \equiv \mathrm{CH} & \mathrm{H} & \mathrm{H}\end{array}$

$(7 \mathbf{a}-\mathbf{d})$

SCHEMe 23<smiles>[R]c1ccc(CNc2ccc3ncnc(Nc4cccc(Br)c4)c3c2)cc1</smiles>

$(\mathbf{8 a}-\mathbf{b}) \mathrm{R}=\mathbf{8} \mathbf{a}-\mathrm{OH} ; \mathbf{8 b}-\mathrm{Cl}$<smiles>[R]c1ccc2ncnc(Nc3ccc(F)c(Cl)c3)c2c1</smiles>

(9a-c) R 9a- $\mathrm{NHCO}\left(\mathrm{CH}_{2}\right)_{2} \mathrm{Br}$;

9b $-\mathrm{NHCO}\left(\mathrm{CH}_{2}\right)_{2} \mathrm{I} ; \mathbf{9 c}-\mathrm{NH}_{2}$

SCHEME 24

evaluated for their function as EGFR inhibitors by applying radioiodination. All these compounds were further evaluated for potential SPECT activity for molecular imaging of breast cancer [20] (see Scheme 24).

A series of novel 6-furanylquinazoline derivatives (1013) were subsequently evaluated for their biological activity as a potent ErbB-1/ErB-2 tyrosine kinase inhibitor [21] (see Schemes 25 and 26).

A series of quinazoline derivatives (14-17) were evaluated for their activity as potent inhibitors of specific isoforms of Cdc2-like kinases (Clk) and dual specificity tyrosinephosphorylation regulated kinases (Dyrk) [22] (see Schemes 27 and 28).
New combi-triazenes $(\mathbf{1 8}, \mathbf{1 9})$ for targeting solid tumors express the epidermal growth factor receptor (EGFR) or its closest homologue HER2 (see Scheme 29).

A series of novel quinazoline derivatives $(\mathbf{2 0 a}-\mathbf{c})$ showed potent ALK5 inhibitory activity [23] (see Scheme 30).

Quinazoline-based (21a-b) anticancer molecule is dual irreversible kinase inhibitors [24] (see Scheme 31).

A series of quinazoline derivatives (22a-b) were evaluated for their biological activity against tyrosine kinase (EGFR) [25] (see Scheme 32).

A series of 4-piperazin-1-yl-quinazoline template based aryl and benzyl thiourea derivatives (23-26) showed potent, selective, and orally bioavailable antagonist of 
<smiles>CS(=O)(=O)CCNCc1ccc(-c2ccc3ncnc(Nc4ccc(OCc5cccc(F)c5)c(Cl)c4)c3c2)o1</smiles>

SCHEME 25<smiles>CN(CCS(C)(=O)=O)Cc1ccc(-c2ccc3ncnc(Nc4ccc(OCc5cccc(F)c5Cl)c(Cl)c4)c3c2)o1</smiles>

12

13

SCHEME 26<smiles>c1csc(CNc2ncnc3ccc(-c4ccc5c(c4)OCO5)cc23)c1</smiles><smiles>CN(Cc1cccs1)c1ncnc2ccc(-c3ccc4c(c3)OCO4)cc12</smiles>

SCHEME 27<smiles>Cc1nc(CN(C)c2ncnc3ccc(-c4ccc5c(c4)OCO5)cc23)cs1</smiles>

16<smiles>CC(C)(C)CNc1ncnc2ccc(-c3ccc4c(c3)OCO4)cc12</smiles>

17

SCHEME 28<smiles>C=COC(=O)N(C)/N=N/c1ccc2ncnc(Nc3cccc(Cl)c3)c2c1</smiles>

18<smiles>C=COC(=O)N(CC[NH2+]C)N=Nc1ccc2ncnc(Nc3cccc(Cl)c3)c2c1</smiles>

19

SCHEME 29 


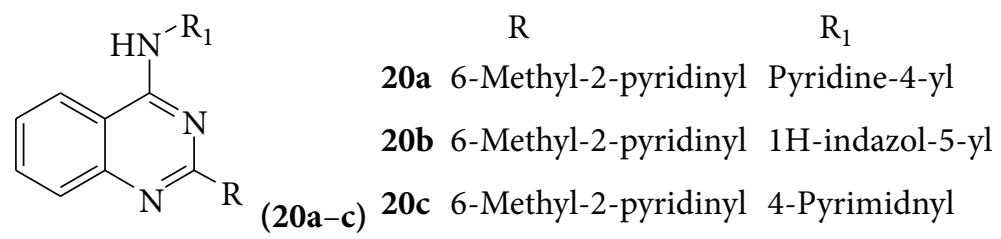

SCHEME 30<smiles>[R]c1ccc(COC2=CC(=O)C(Nc3ncnc4cc([R])c(NC(=O)/C=C\CN(C)C)cc34)=CC2=O)cc1[R]</smiles>

$$
\begin{array}{rrrc} 
& \mathrm{R} & \mathrm{R}_{1} & \mathrm{R}_{2} \\
\text { 21a } & -\mathrm{F} & \mathrm{H} & -\mathrm{OCH}_{3} \\
\text { 21b } & -\mathrm{F} & -\mathrm{F} & -\mathrm{OCH}_{3}
\end{array}
$$

SCHEME 31<smiles>[R]C/C=C/C(=N)Nc1ccc([R3])c([R2])c1</smiles>

$(22 a-b)$

SCHEME 32<smiles>[R1]CCCOc1cc2ncnc(N3CCN(C(=S)NCc4ccc([R2])nc4)CC3)c2cc1OC</smiles><smiles></smiles>

SCHEME 33

platelet-derived growth factor (PDGF) receptor [26] (see Schemes 33 and 34).

A series of 4-[4-(N-substituted(thio)carbamoyl)-1piperazinyl]-6,7-dimethoxyquinazoline derivatives (27a-b) were evaluated for their potential antagonizing activity against Platelet-Derived Growth Factor Receptor (PDGF) [27] (see Scheme 35).

A series of quinazoline derivatives (28a-b and 29a-b) showed potent inhibitory activity against Aurora kinase [28] (see Scheme 36).

A series of 1-acetanilide-4-aminopyrazole substituted quinazoline derivatives $(\mathbf{3 0 a}-\mathbf{c})$ were subsequently evaluated for their inhibitory activity against Aurora B kinase as potent antitumour agents [29] (see Scheme 37).

Some quinazolines were evaluated as antitumor agents, the biological activity of some 2,3-di-substituted 8arylamino-3H-imidazo[4,5-g]quinazoline derivative (31 and 32) as a potent antitumor agent. Compound 32 possessed the highest activity on the A549 cell line [30] (see Scheme 38).

A series of novel C-5 substituted anilinoquinazoline derivatives and evaluated their activity as an inhibitor of epidermal growth factor receptor tyrosine [31]. Few novel 4,6disubstituted quinazoline derivatives (33-36) showed good 
<smiles>COc1cc2c(N3CCN(C(=S)NCc4cnc(C(F)(F)F)cn4)CC3)ncnc2cc1OCCN1CCCCC1</smiles>

25<smiles>COc1cc2c(N3CCN(C(=S)Nc4ccc(-c5ccccn5)cc4)CC3)ncnc2cc1OCCN1CCCCC1</smiles>

SCHeme 34<smiles>[R]c1cc2ncnc(N3CCN(C(=O)Nc4ccc(Oc5ccccc5)cc4)CC3)c2cc1[R]</smiles><smiles>[R]OC(=O)OC</smiles>

(27a-b)

SCHEME 35<smiles>[R2]C(=O)Nc1ncc(Nc2ncnc3cc(OCC([R])CN4CCCCC4)c([R16])cc23)cn1</smiles>

$\begin{array}{llll}\mathrm{R} & \mathrm{R}_{1} & \mathrm{R}_{2}\end{array}$ 28a $\mathrm{H} \quad \mathrm{OCH}_{3} \quad 3-\mathrm{Cl}-\mathrm{C}_{6} \mathrm{H}_{4}$ 28b $\quad \begin{array}{llll}\mathrm{OCH}_{3} & \mathrm{C}_{6} \mathrm{H}_{5}\end{array}$<smiles>[R2]C(=O)Nc1ncc(Nc2ncnc3cc(OCCCN4CCOCC4)c([R16])cc23)cn1</smiles>

$\mathrm{R}_{1} \quad \mathrm{R}_{2}$ 29a $-\mathrm{OCH}_{3}$ 3-Cl-4F- $\mathrm{C}_{6} \mathrm{H}_{3}$ 29 b $-\mathrm{OCH}_{3} \quad 3-\mathrm{Cl}-\mathrm{C}_{6} \mathrm{H}_{4}$

SCHEME 36<smiles>[R2]CCCOc1cc2ncnc(Nc3cnn(CC(=O)Nc4cccc(F)c4F)c3)c2cc1[R1]</smiles><smiles>CN(CCO)CCO</smiles> 
<smiles>CCCCCn1c(C(C)C)nc2cc3c(Nc4ccc(F)cc4)ncnc3cc21</smiles>

SCHEMe 38<smiles>[R]N1CCC(Oc2cc(OC)cc3ncnc(Nc4ccc(F)c(Cl)c4)c23)CC1</smiles>

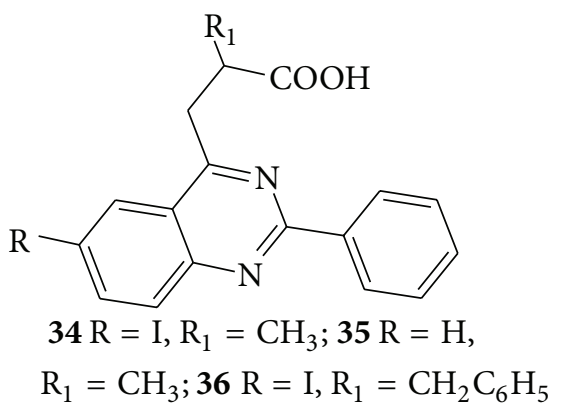

32
Scheme 39<smiles>[R]NC(=O)Nc1nc(N[R])c2cc([N+](=O)[O-])ccc2n1</smiles>

$\mathrm{R}$

$\mathrm{R}_{1}$

37a 3,4-Cl- $\mathrm{C}_{6} \mathrm{H}_{3}$ 4-COOH$-\mathrm{C}_{6} \mathrm{H}_{4}$

37b $4-\mathrm{CF}_{3}-\mathrm{C}_{6} \mathrm{H}_{4} 4-\mathrm{COOH}-\mathrm{C}_{6} \mathrm{H}_{4}$

37 c $3-\mathrm{CF}_{3}-\mathrm{C}_{6} \mathrm{H}_{4} \quad 4-\mathrm{COOH}-\mathrm{C}_{6} \mathrm{H}_{4}$ (33a-b) 33a $\mathrm{R}=-\mathrm{CH}_{3} ; 33 \mathbf{b} \mathrm{R}=\mathrm{H}$

$(37 a-c)$

SCHEME 40<smiles>O=C(O)c1ccc(Nc2nc(Nc3ccc(Oc4ccccc4)cc3)nc3ccc([N+](=O)[O-])cc23)cc1</smiles>

38 anti-inflammatory and anticancer activity (cytotoxic) against U937 leukemia cell lines [32] (see Scheme 39).

A series of quinazoline derivatives (37 and 38) have strong inhibition on human Pin1 [33] (see Scheme 40).

A series of quinazoline derivatives (39-42) were evaluated for their biological activity as potential antitumor agents [34] (see Schemes 41 and 42).

HEPG2 human liver cell line was proved to be sensitive toward compounds $39, \mathbf{4 0}$, and 41 with $\mathrm{IC}_{50}$ concentration range of $4.17-5.99 \mu \mathrm{g} / \mathrm{mL}$. Regarding HELA cervix cell line, higher sensitivity was observed with compounds 39, 41, and 42 with $\mathrm{IC}_{50}$ concentration range of $3.56-5.39 \mu \mathrm{g} / \mathrm{mL}$. With regard to broad-spectrum antitumor activity, compounds 42 , 41, and 39 showed $\mathrm{IC}_{50}$ of $3.35-5.59 \mu \mathrm{g} / \mathrm{mL}$ against the three cell lines.
Microwave-assisted synthesis and the SAR studies of modified 9-oxo-thia-zolo[5,4-f] quinazoline-2-carbonitriles allowed identification of new amidine and imidate derivatives as potent and dual CDK1/GSK-3 inhibitors. Combination of lead optimization and molecular modeling studies allowed a dual CDK1/GSK-3 inhibitor with submicromolar values [35]. Novel 2,3-disubstituted quinazoline-4(3H)-ones (43) were screened for cytotoxicity and for antiviral activity against influenza A [36]. The 6-Arylbenzimidazo [1,2-c]quinazoline derivatives were act as a tumor necrosis factor alpha (TNF$\alpha)$ production inhibitors. These compounds were tested for their in vitro ability to inhibit the lipolysaccharide (LPS) induced TNF- $\alpha$ secretion in the human promyelocytic cell line HL-60. The compound 6-Phenyl-benzimidazo [1,2c]quinazoline, coded as G1, resulted as the most potent 
<smiles>Cc1ccc(-c2nc(Sc3ncccc3[N+](=O)[O-])c3cc(Cl)ccc3n2)cc1</smiles>

39<smiles>CCOc1ccc(NC(=O)CSc2nc(-c3ccc(C)cc3)nc3ccc(Cl)cc23)cc1</smiles>

40

SCHEME 41<smiles>Cc1ccc(-c2nc(SCC#N)c3cc(Cl)ccc3n2)cc1</smiles>

41<smiles>Cc1ccc(-c2nc(NN)c3cc(Cl)ccc3n2)cc1</smiles>

42

SCHEME 42<smiles>[R]OS(=O)(=O)C1C=CC(N2C(C3C=CC=CC3)=NC3=CC([R])C([R])C=C3C2[R])=CC1</smiles>

SCHEME 43

inhibitor and with no significant cytotoxic activity. Thus, 6arylbenzimidazo [1,2-c] quinazoline derivatives may have a potential as anti-inflammatory agents [37]. Docking studies of few synthesized 6,7-dialkoxy-4-anilinoquinazoline derivatives which showed EGFR-TK inhibitory activity were conducted [38]. The 3-(3-methylisoxazol-5-yl) and 3-(pyrimidin2-yl)-2 styrylquinazolin-4(3H)-ones $(44,45)$ were prepared by refluxing in acetic acid the corresponding 2methylquinazolinones with the benzoic aldehyde and tested for their in vitro antileukemic activity against L-1210 (murine leukemia), K-562 (human chronic myelogenous leukemia), and HL-60 (human leukemia) cell lines showing in some cases good activity [39] (see Scheme 43).

6.2. Quinazolinones as Antibacterial Activity. A series of new 2-[2-(2,6- dichlorophenyl) amino] phenyl methyl-3-[(5substitutedphenyl)-1,5-dihydro-1H-pyrazol-3-yl-amino]-6iodoquinazolin-4(3H) ones compounds (46) were tested for their antibacterial activity in vitro by measuring zone of inhibition in $\mathrm{mm}$ against different strains like two gram positive bacteria, namely, Staphylococcus aureus and Bacillus subtilis, and two gram negative bacteria, namely, Escherichia coli and Certium at two different concentrations $100 \mu \mathrm{g} / \mathrm{mL}$ and $50 \mu \mathrm{g} / \mathrm{mL}$ [40]. Quinazolinone derivatives (DK-1, DK-2, DK-3, DK-4, DK-5, DK-6, and DK-7) by treating 2-chloro$\mathrm{N}$-(4-oxo-2-phenylquinazolin-3 $(4 \mathrm{H})$-yl)acetamide with the different substituted phenols. The synthesized compounds were evaluated for antibacterial activity by cup plate method by measuring inhibition zone. The compound DK-2 (47) showed more potent antibacterial activity than the standard drug ampicillin [41]. A series of quinazolines derivatives were evaluated for their biological activity on various bacterial cultures [42] (see Schemes 44 and 45).

Compounds 49 and 50 showed comparative activity against K. pneumoniae as compared to ciprofloxacin. Compound 48 exhibited greater activity against $S$. sonnei, E. faecalis, and $P$. aeruginosa as compared to ciprofloxacin. A series of some novel substituted iodoquinazoline derivatives are evaluated for their antimicrobial activity [43]. Compounds 52 and $\mathbf{5 3}$ showed remarkable activity towards the gram negative bacteria E. coli, whereas compounds 51, 52, and 54 showed potent activity against $S$. aureus, B. subtilis, S. Cerevisiae, and C. albicans (see Scheme 46). 
<smiles>O=c1c2cc(I)ccc2nc(Cc2ccccc2Nc2c(Cl)cccc2Cl)n1NC1=NNC(c2ccccc2)C1</smiles>

46<smiles>O=C(COc1ccc([N+](=O)[O-])cc1)Nn1c(-c2ccccc2)nc2ccccc2c1=O</smiles>

47

SCHEME 44<smiles>Cc1ccc2nc(N3CCOCC3)nc(-c3ccccc3)c2c1</smiles>

48<smiles>Cc1ccc2nc(N3CCOCC3)nc(-c3ccc(N(C)C)cc3)c2c1</smiles>

49<smiles>Cc1ccc2nc(N3CCCCC3)nc(-c3ccc(C(=O)O)cc3)c2c1</smiles>

50

SCHEME 45<smiles>Ic1ccc2nc(-c3cccs3)nc(OCc3nc4ccccc4[nH]3)c2c1</smiles>

51<smiles>Ic1ccc2nc(-c3cccs3)n3c4ccccc4nc3c2c1</smiles>

52<smiles>O=c1[nH]c(-c2cccs2)nc2ccc(I)cc12</smiles>

53<smiles>S=c1nc2c3cc(I)ccc3nc(-c3cccs3)n2[nH]1</smiles>

54

SCHEME 46

The 3-[5-(4-substituted phenyl)-1,3,4-thiadiazole-2yl]-2-styryl quinazoline-4(3H)-ones (55) reported their antibacterial and antifungal activity [44]. The 6,7,8,9tetrahydro-5(H)-5-nitrophenylthiazolo[2,3-b]-quinazolin$3(2 \mathrm{H})$-one derivatives showed antimicrobial activity [45]. The 3-[(2-hydroxy-quinolin-3-ylmethylene)-amino]-2-phenyl$3 \mathrm{H}$-quinazolin-4-one (56) and its metal (II) complexes were reported for their antimicrobial activity [46]. Some quinazoline derivatives (57) act as potential antimicrobial agents [47] (see Schemes 47 and 48).

Condensing 2-methyl/phenyl/chloro methyl disubstituted benzooxazine-4-one and 1-(2-amino ethyl)-4-substituted benzylidene-2-phenyl-1H-Imidazoles-5(4H)-one gave imidazolo-quinazoline-4-one derivatives. These compounds have shown promising antibacterial and antifungal activity [48]. The antibacterial activities of substituted quinazolines against bacterial strains E. coli, P. aeruginosa, B. subtilis, and $S$. aureus were investigated. The sensitivity of the gram positive bacteria to the tested quinazolines was higher than that of gram negative bacteria. The most effective of quinazoline structure series were condensed $[1,2,4]$ triazoloquinazolines and $10 \mathrm{H}-[1,2,4]$ triazino[5,4-b]quinazolin-10-ones [49]. The 6-bromo-2-alkyl/aryl-3\{[phenyl(phenyldiazenyl)methylene]amino\}quinazolin-4(3H)-ones were exhibited antimicrobial activities [50].

6.3. Quinazolinones as Antifungal Activity. Octahydroquinazoline (58) was obtained by a modification of the Biginelli reaction with phenacyl bromide and bromo malononitrile to furnish thiazolo [2,3-b] quinazoline and they found the interaction of compound with formamide, formic acid, and phenyl isothiocyanate yielded the corresponding pyrimidino thiazolo [2,3-b] quinazolines and exhibited antifungal activity against Candida albicans [51].

A series of few novel S-substituted-6-fluoro-4-alkyl (aryl) thioquinazoline derivatives $(\mathbf{5 9} \mathbf{a}-\mathbf{c})$ were evaluated for their pharmacological activity as antifungal [52] (see Scheme 49). 
<smiles></smiles>

55<smiles>Oc1nc2ccccc2cc1/C=N/N1CC2C=CC=CC2N=C1c1ccccc1</smiles>

56

Scheme 47<smiles>[R]c1nc2ccccc2c(=O)n1-c1ccc(-c2nnc(NC(=O)[AlH2])s2)cc1</smiles>

57
$\mathrm{R}=2$-chlorophenyl, $\mathrm{Ar}=$ different aryl groups

Scheme 48<smiles>O=C1CCCC2=C1C(c1c(F)c(F)cc(F)c1F)NC(=S)N2</smiles>

58<smiles>[R]c1ncnc2ccc(F)cc12</smiles>

$(59 a-c)$

Scheme 49<smiles>O=c1oc2c(Cl)cc(Cl)cc2c(=O)n1-c1ccccc1</smiles>

60<smiles>O=c1[nH]c2ccccc2c(=O)n1-c1ccccc1</smiles>

61<smiles>[R]Sc1ncnc2ccccc12</smiles>

$(62 a-d)$
$59 \mathbf{a}=-\mathrm{SCH}_{2} \mathrm{CH}=\mathrm{CH}_{2}$,

$59 \mathbf{b}=-\mathrm{SCH}_{2} \mathrm{CH}_{2}-\mathrm{CH}_{3}$,

$59 \mathrm{c}=-\mathrm{SCH}_{2} \mathrm{CH}_{3}$

SCHEME 50

All of these compounds exhibited good antifungal activity, especially compound 59c, having a wide spectrum of bioactivity; it shows potent inhibitory activity on the growth of most of the fungi with $\mathrm{EC}_{50}$ values ranging from 8.3 to $64.2 \mu \mathrm{g} / \mathrm{mL}$.

6.4. Antitubercular Activity. Some quinazolinones were reported as potent chemotherapeutic agents in the treatment of tuberculosis (TB). For example 3-aryl-6,8-dichloro$2 \mathrm{H}$-1,3-benzoxazine-2,4(3H)-diones (60) and 3-arylquinazoline-2,4(1H,3H)-diones $(61)$ are as anti-TB agents and quinazolinone derivatives as anti-TB agents [4].

A series of 2-alkylthio-6-iodo-3-substituted-quinazolin4-one derivatives were screened for their in vitro anti-TB activity against Mycobacterium tuberculosis strain HRv [53]. A series of quinazoline derivatives $(\mathbf{6 2 a} \mathbf{a}-\mathbf{d})$ were evaluated for their pharmacological activity as anti-TB [54] (see Scheme 50).

1,4-Disubstituted 3-[3'-( $2^{\prime}$-phenyl- $4^{\prime}$-oxo-quinazolinyl)]2-azetidinones showed antifertility activity [55]. 6-substituted-2-phenyl-3-(5-substituted mercapto-1,3,4-thiadiazole-2-yl)quinazoline-4- $(3 \mathrm{H})$-ones showed anti-TB activity [56]. Most of the synthesized compounds exhibited anti-TB activity against the strains of Mycobacterium tuberculosis, M. avium, M. fortuitum, M. kansasii, and M. intracellulare. The modification process with various hydrophobic chains clearly suggests the existence of hydrophobic pocket in the active site of the target of various strains of Mycobacterium spp., which eventually raise the therapeutic efficacy. 
<smiles>[R]C=Nn1c(C)nc2ccccc2c1=O</smiles>

$(63 a-c)$

$$
\begin{array}{ccc} 
& \mathrm{R} & \mathrm{R}_{1} \\
\text { 63a } & \mathrm{C}_{6} \mathrm{H}_{5} & 2-\mathrm{OH}-\mathrm{C}_{6} \mathrm{H}_{4} \\
\text { 63b } & \mathrm{C}_{6} \mathrm{H}_{5} & 4-\mathrm{OCH}_{3}-\mathrm{C}_{6} \mathrm{H}_{4} \\
\text { 63c } & \mathrm{C}_{6} \mathrm{H}_{5} & \mathrm{C}_{6} \mathrm{H}_{5}
\end{array}
$$

SCHEME 51<smiles>Cc1ccc2c(c1)C(Nc1ccc(Cl)c(Cl)c1)NC=N2</smiles>

64<smiles>CSC1=NC2C=CC=CC2C(=O)N1/N=C1\C(=O)Nc2ccccc21</smiles>

65

SCHEME 52

6.5. Quinazoline as Antiviral Agents. A series of Schiff bases of some 2-phenyl quinazoline-4(3) $\mathrm{H}$-one derivatives are evaluated for their activity as antiviral agents [57] (see Scheme 51).

Compound 63a exhibited antiviral activity against herpes simplex virus-1 (KOS), herpes simplex virus-2(G), herpes simplex virus-1 (TK- KOS ACV), and vaccinia virus in HEL cell culture at selectivity index of 100, 100, 100, and 125 , respectively, whereas cytotoxicity was observed at $100 \mu \mathrm{g} / \mathrm{mL}$. Compounds 63b and 63c demonstrated good activity against herpes simplex virus-1 (KOS), herpes simplex virus-2 $(G)$, and vaccinia virus. The protein kinase inhibitory activity and anticytomegaloviral activity showed few quinazoline (64) compounds [58]. Quinazolinones act as anti-HIV activity whereas compounds 3-amino-2methyl mercaptoquinazolin-4(3H)-one (65) were synthesized by condensing the acidic imino group of isatin with formaldehyde and secondary amines and evaluated for antiHIV activity against HIV-1 III B in MT-4 cells [59] (see Scheme 52).

6.6. Quinazolinones as Antimutagenic Activity. The (S)4-aminoquinazoline alcohols (66) were prepared from enantiomerically pure from (S)-quinazolinone alcohols. Mutagenic and antimutagenic properties of the (S)-4aminoquinazoline alcohols were investigated by using Salmonella typhimurium and E. coli WP2uvrA tester strains at $0.01,0.1$, and $1 \mathrm{lg} /$ plate concentrations. (S)-4aminoquinazoline alcohols were found to be genotoxically safe at the tested concentrations. Among the tested (S)-4aminoquinazoline alcohols, the best antimutagenic activity was obtained with a methyl derivative at $0.1 \mu \mathrm{g} /$ plate dose [60].
6.7. Quinazolinones as Anticoccidial Activity. A series of 3-(2-(2-methoxyphenyl)-2-oxoethyl) quinazolinone derivatives (67) are anticoccidial agents by modifying the quinazoline ring of febrifugine against Eimeria tenella in the chicken at a dose of $9 \mathrm{mg} / \mathrm{kg}$. 3-(2-(2-Methoxyphenyl)2-oxoethyl) quinazolinone derivatives (68) possess high anticoccidial activity and may serve as a lead compound for the development of anticoccidial drugs in the future [61]. A series of 4-(2methoxyphenyl)-2-oxobutylquinazoline (69) derivatives are reported for their anticoccidial activity [62] (see Schemes 53 and 54).

6.8. Anti-Inflammatory and Analgesics Agents. A series of quinazoline derivatives $(\mathbf{7 0}, \mathbf{7 1})$ showed potent analgesic and anti-inflammatory activity. All these compounds demonstrated potent activity as anti-inflammatory analgesic more than the reference compound indomethacin [63] (see Scheme 55).

A series of novel 2-(2,4-disubstituted-thiazole-5-yl)-3aryl-3H-quinazoline-4-one (72) derivatives which became good inhibitors of $\mathrm{NF} \kappa \mathrm{B}$ and $\mathrm{AP}-1$ mediated transcription activation [64]. A series of 3-phenyl-2-substituted-3Hquinazolin-4-one (73a-c) derivatives were evaluated for their pharmacological activity as analgesic and anti-inflammatory agents [65] (see Scheme 56).

A series of some novel 2,3-disubstituted quinazolinone derivatives by condensing 2-methyl/2-phenyl/6-bromo2-methyl/6-bromo-2-phenyl/6,8-dibromo-2-methyl/6,8-

dibromo-2-phenyl benzoxazines with compounds containing amino group were evaluated for their analgesic activity and they reported that compound (74) shows promising analgesic activity compared to standard drug Diclofenac sodium [66]. Various 2-(substituted phenyl methylene imino) amino acetyl methylene-3-( $2^{\prime}$-substituted indol- $3^{\prime}$-yl)-halo substituted$4(3 \mathrm{H})$ quinazolinone and 2-(substituted phenyl amino 
<smiles>CC(O)c1nc(N)c2ccccc2n1</smiles>

66<smiles>COc1ccccc1C(=O)Cn1cc2ccccc2nc1=O</smiles>

67

SCHEME 53<smiles>COc1ccccc1C(=O)Cn1cc2ccccc2nc1=O</smiles>

68<smiles>CC(=O)c1ccccc1CCC(=O)CN1C=NCc2ccccc21</smiles>

69

SCHEME 54<smiles>c1ccc(-c2nc(N3CCN(c4ccccc4)CC3)c3ccccc3n2)cc1</smiles>

70

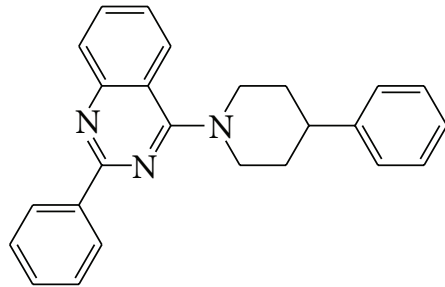

71

SCHEMe 55<smiles>[R]Nc1nc(C)c(-c2nc(Nc3ccc(Cl)cc3)c3ccccc3n2)s1</smiles>

(72a-b) 72a R $=-\mathrm{CH}_{3}$; $72 \mathbf{b ~ R}=3 \mathrm{Cl}-\mathrm{C}_{6} \mathrm{H}_{4}$<smiles>[R]c1ccccc1-c1ccccc1</smiles>

SCHEMe 56 methylene acetyl- $4^{\prime}$-oxo-1' ${ }^{\prime}$-thiazolidinyl-3- $\left(2^{\prime \prime}\right.$-substituted indol- $3^{\prime \prime}$-yl) $4(3 \mathrm{H})$-quinazolinones reported that compound (75) exhibited good anti-inflammatory activity [67] (see Scheme 57).

A series of novel 8/10-trifluoromethyl-substitutedimidazo [1,2-c] quinazolines are evaluated in vivo for their anti-inflammatory activity and in silico to recognize the hypothetical binding motif with the cyclooxygenase isoenzymes (COX-1 and COX-2) employing GOLD (CCDC, 4.0.1 version) software and found that compounds (76 and 77) show good anti-inflammatory activity against standard: indomethacin [68] (see Scheme 58).
A series of 5-(4-chlorophenyl)-9-iodo-3-substituted1,2,4-triazolo[4,3-c]quinazoline and 2-(4-chlorophenyl)-6iodo-4-substituted-quinazoline were evaluated as antiinflammatory agents. The result revealed that some compounds have activity comparable to indomethacin [69]. A number of substituted oxoquinazolines were reported for their analgesic and antibacterial activity [70]. A series of novel 3-(6-substituted-1,3-benzothiazole-2-yl)-2-[\{(4substituted phenyl)amino methyl] quinazolines-4(3H)-ones and quinazolines-4-one derivative were investigated for their anti-inflammatory and antibacterial activity [71]. A series of some 2-[(E)-2-furan-2-yl-vinyl]-quina-zolin-4(3H)-ones 
<smiles>CCCCCCc1nc2c(Br)cc(Br)cc2c(=O)n1N</smiles>

74<smiles>COc1ccccc1C1SCC(=O)N1NCC(=O)CC1=Nc2ccc(I)cc2C(=O)C1C1=CC2C=CC=CC2N1</smiles>

75

SCHEME 57<smiles>NC(=O)c1c(C(F)(F)F)cc(-c2ccccc2)c2c1N=C(c1ccc(Cl)cc1)N1CCN=C21</smiles>

76<smiles>NC(=O)c1c(-c2ccccc2)cc(C(F)(F)F)c2c1N=C(c1ccc(O)cc1)N1CCN=C21</smiles>

77

SCHEME 58<smiles>[R7]C=Cc1nc2ccccc2c(=O)n1-c1nnc([R])s1</smiles>

$(78 \mathbf{a}-\mathrm{c})$

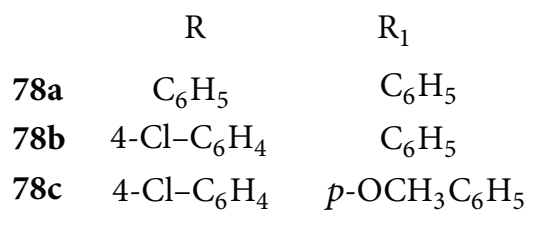

$78 \mathbf{b} \quad 4-\mathrm{Cl}-\mathrm{C}_{6} \mathrm{H}_{4} \quad \mathrm{C}_{6} \mathrm{H}_{5}$

78c $\quad 4-\mathrm{Cl}-\mathrm{C}_{6} \mathrm{H}_{4} \quad p-\mathrm{OCH}_{3} \mathrm{C}_{6} \mathrm{H}_{5}$

SCHEME 59

incorporated into pyrazoline, isoxazoline, pyrimidine, or pyrimidine-thione ring systems at position 3 of the quinazoline ring. These compounds showed antimicrobial activity and anti-inflammatory effect of [72].

6.9. Quinazoline as Antidepressant and Anticonvulsant. A series of novel 3-[5-substituted 1,3,4-thiadiazole-2-yl]-2styryl quinazoline-4(3H)-ones $(\mathbf{7 8 a} \mathbf{a}-\mathbf{c})$ derivatives were evaluated for their activity as antidepressant agents [73] (see Scheme 59).

All the compounds showed anticonvulsant activity in MES screen; however, compound 78a showed potency similar to standard drug (phenytoin, carbamazepine) without any neurotoxicity.

A series of some novel 3-[5-substituted 1,3,4-thiadiazole2-yl]-2-styryl quinazoline-4(3H)-one.

$(79 a-c)$ derivatives were evaluated for their activity as CNS depressant and anticonvulsant agents [74] (see Scheme 60).

Compounds with the above substituents showed potent CNS depressant activity. Compound 79a showed anticonvulsant activity at 0.5 and $4 \mathrm{~h}$ in different test models, whereas 79c showed anticonvulsant activity at $4 \mathrm{~h}$ in MES screen and at 0.5 and $4 \mathrm{~h}$ in subcutaneous PTZ screen.

The 3-aryl-4(3H)-quinazolinone-2 carboxaldehydes, their corresponding Schiff's base, and thiosemicarbazone derivatives reported (80-82) as anticonvulsants [75] (see Scheme 61).

Several 1-(4-substitutedphenyl)-3-(4-oxo-2-phenyl/ethyl$4 \mathrm{H}$-quinazolin-3-yl)-urea derivatives (83a-h and 84a-h) were screened for their anticonvulsant activity by MES and scPTZ-induced seizure models in mice and found that these compounds were active in the MES screen whereas some compounds were found to be active in the scPTZ screen [76] (see Scheme 62).

Two regioisomer series, 2-(3-ethyl-4(3H)-quinazolinone2-ylmercaptoacetylhydrazono)-3-alkyl/3-aryl-5-methyl-4thiazolidinones (85) and 2-arylimino-3-(3-ethyl-4 $(3 \mathrm{H})$ quinazolinone-2-yl mercaptoacetylamino)-5-methyl-4-thiazolidinones were reported for their anticonvulsant activity [77]. Substituted quinazolinonyl-2-Oxo/thiobarbituric acid derivatives showed anticonvulsant activity against MES and scPTZ models [78]. A series of halogenated derivatives, 3-methyl, 3-ethyl and 3-phenyl-6-mono, and 
<smiles>[R]c1nnc(-n2c(/C=C/[AlH2])nc3ccccc3c2=O)s1</smiles><smiles>[R]Oc1ccccc1</smiles>

SCHEME 60<smiles>NC(=S)N/N=C\c1nc2ccc(I)cc2c(=O)n1-c1ccc(F)cc1</smiles>

80<smiles>CNC(=S)N/N=C\c1nc2ccc(I)cc2c(=O)n1-c1ccc(F)cc1</smiles>

81<smiles>CCNC(=S)N/N=C\c1nc2ccc(I)cc2c(=O)n1-c1ccc(F)cc1</smiles>

82

SCHEME 61<smiles>[R1]c1ccc(NC(=O)Nn2c(CC)cc3ccccc3c2=O)cc1</smiles>

$(83 a-h)$<smiles>[R1]c1ccc(NC(=O)Nn2c(C(C)(C)C)cc3ccccc3c2=O)cc1</smiles>

$(84 a-h)$

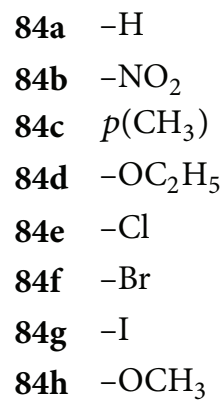

SCHEME 62

6,8-disubstituted-3H-quinazolin-4-one derivatives exhibited anticonvulsant activity and phenobarbitone sodium was used as a reference drug [79]. Some thiadiazolyl and thiazolidinonyl quinazoline-4(3H)-ones (86) screened them for anticonvulsant activity against MES induced convulsions in animal models [80] (see Scheme 63).

A series of novel 3-[5-substituted phenyl-1,3,4 thiadiazole-2-yl]-2-styryl quinazoline-4(3H)-one is screened for antidepressant activities with the help of the forced swim pool method and found that compound (87) was most active against antidepressant activity [73]. The 3-[5-substituted1,3,4-thiadiazole-2-yl]-2-styryl quinazoline-4(3H)-ones $(\mathbf{8 8})$ and their antidepressant activity were screened with the help of forced swim pool method [73] (see Scheme 64).

6.10. Quinazolinones as Antimalarial Agents. The 2,4-diamino-6-[(aryl)thio]quinazoline compounds were known to their antimalarial properties wherein the 4-amino group was replaced by hydrazine and hydroxyamino moieties and they found that such changes reduce markedly the antimalarial properties of this series. The compound (89) was tested against a normal drug-sensitive strain of Plasmodium berghei in mice by the parenteral route [81]. A series of quinazoline derivatives (90) were evaluated for their antiplasmodial activity [82] (see Scheme 65).

Compounds 90a and 90c show a high potential activity (resp., W2 $\mathrm{IC}_{50}$ values $=0.95$ and $1.3 \mu \mathrm{M}$ ) in comparison with chloroquine and doxycycline. A series of new 6-ureido-4anilinoquinazolines (91-94) were evaluated for their potent activity as antimalarial agents [83] (see Scheme 66).

A series of 4-thiophenoxy-2-trichloromethyquinazolines derivatives (95a-b) were evaluated for their antiplasmodial activity against the human malarial parasite Plasmodium falciparum was determined [84]. Compounds 95a and 95b showed good activity against K1 Plasmodium falciparum $\left(\mathrm{IC}_{50}=1.9 \mu \mathrm{M}\right.$ and $0.9 \mu \mathrm{M}$, resp.), whereas $\mathrm{IC}_{50}$ value of chloroquine is $0.5 \mu \mathrm{M}$. A series of $(\mathbf{9 6 a}-\mathbf{d})$ in 4 -aryl2-trichloromethylquinazolines (96a-d) were evaluated for their antiplasmodial activity [85] (see Scheme 67).

Compounds with the above substituents exhibited favourable antiplasmodial activity on THP1 and HepG2 human cell lines.

6.11. Quinazolinones as Antioxidant Activity. A series of novel thiazolo quinazoline derivatives by condensation of different aromatic aldehydes with 4-nitro aniline are screened for 
<smiles>[Y]c1ccc2c(c1)N=C(C)C(NCc1nnc(C3C(=O)CSC3c3ccccc3)s1)C(=O)C2NCc1nnc(NCC2C(=O)NC([X])NC2=O)s1</smiles>

$85 \mathrm{X}=\mathrm{H}, \mathrm{R}=\mathrm{H}$ or $p-\mathrm{OCH}_{3}$

$86 \mathrm{X}=\mathrm{H}$ or $\mathrm{Cl}, \mathrm{X}^{\prime}=\mathrm{O}$

SCHEME 63<smiles>O=c1c2ccccc2nc(/C=C/c2ccccc2)n1-c1nnc(-c2ccccc2)s1</smiles>

87<smiles>[R]c1nnc(N2C(=O)C3C=CC=CC3N=C2/C=C/[Al])s1</smiles>

$88 \mathrm{Ar}=\mathrm{C}_{6} \mathrm{H}_{5}, \mathrm{R}=p \mathrm{OCH}_{3}$

SCHEME 64<smiles>Nc1nc(N)c2cc(S3=CC=CC(C(F)(F)F)=C3)ccc2n1</smiles>

89<smiles>[R]c1cc(Cc2nc(CS(=O)(=O)c3ccc(C)cc3)nc3ccc([N+](=O)[O-])cc23)cc([R])c1[R]</smiles>

90
$\begin{array}{llll}\mathrm{R} & \mathrm{R}_{1} & \mathrm{R}_{2}\end{array}$

90a $\mathrm{CF}_{3} \mathrm{H} \quad \mathrm{H}$

90b $\mathrm{H} \quad \mathrm{F}$ H

90c $\mathrm{Cl} \mathrm{H} \mathrm{H}$

SCHEME 65<smiles>[R]c1ccc(NC(=O)Nc2ccc3ncnc(Nc4ccc([R1])c([R1])c4)c3c2)cc1[R]</smiles>

$91 \mathrm{R}_{1}=\mathrm{H}, \mathrm{R}_{2}=\mathrm{Cl}, \mathrm{R}_{3}=\mathrm{H}, \mathrm{R}_{4}=\mathrm{F}$;

$92 \mathrm{R}_{1}=\mathrm{Cl}, \mathrm{R}_{2}=\mathrm{CH}_{3}, \mathrm{R}_{3}=\mathrm{H}, \mathrm{R}_{4}=\mathrm{F}$;

$93 \mathrm{R}_{1}=\mathrm{CF}_{3}, \mathrm{R}_{2}=\mathrm{Cl}, \mathrm{R}_{3}=\mathrm{H}, \mathrm{R}_{4}=\mathrm{CF}_{3}$;

$94 \mathrm{R}_{1}=\mathrm{CF}_{3}, \mathrm{R}_{2}=\mathrm{Cl}, \mathrm{R}_{3}=\mathrm{OCH}_{3}, \mathrm{R}_{4}=\mathrm{OCH}_{3}$.

(91-94)

SCHEME 66

antioxidant activity by DPPH radical assay, nitric oxide scavenging activity, and hydrogen peroxide scavenging activity and reported that synthesized compounds (97-99) were found to be the most potent antioxidant activity [86] (see Scheme 68).
6.12. Antileishmanial Agents. Compounds of both synthetic and natural origin comprising a diverse group of chemical structure have been reported as antileishmial agents. These include mostly nitrogen heterocyclic such as quinolines, purine, pyrimidine, acidine, phenothiazines, bisbenzamides, 
<smiles>[R]Sc1nc([R])nc2ccccc12</smiles>

$(95 a-b)$<smiles>[R]c1nc([R])c2ccccc2n1</smiles>

$\mathrm{R} \quad \mathrm{R}_{1}$ 96a $-\mathrm{CCl}_{3} 4-\mathrm{F}-\mathrm{C}_{6} \mathrm{H}_{4}$ $96 \mathbf{b}-\mathrm{CCl}_{3} 4-\mathrm{Cl}-\mathrm{C}_{6} \mathrm{H}_{4}$ 96c $-\mathrm{CCl}_{3} 4-\mathrm{OCH}_{3}-\mathrm{C}_{6} \mathrm{H}_{5}$ 96d $-\mathrm{CCl}_{3}$ 2-Naphthyl

(96a-d)

SCHEMe 67<smiles>COc1cc(/C=C2\SC3=NC4=C(CCCC4)C(c4ccccc4O)N3C2Nc2ccc([N+](=O)[O-])cc2)cc(OC)c1OC</smiles>

97<smiles>COc1cc(/C=C2\SC3=NC4=C(CCCC4)C(c4ccccc4O)N3C2Nc2ccc([N+](=O)[O-])cc2)ccc1O</smiles>

98<smiles>O=[N+]([O-])c1ccc(NC2/C(=C/c3ccc(O)cc3)SC3=NC4=C(CCCC4)C(c4ccccc4O)N32)cc1</smiles>

99

SCHEMe 68<smiles>ClC1=CCC(C2NC(N3CCOCC3)=NC3=C2CCc2ccccc23)C=C1</smiles>

100<smiles>FC1=CCC(C2NC(N3CCCCC3)=NC3=C2CCc2ccccc23)C=C1</smiles>

101<smiles>FC1=CCC(C2NC(N3CCCC3)=NC3=C2CCc2ccccc23)C=C1</smiles>

102

SCHEME 69

pyrazolol, pyridine, benzothiazole, and imidazolines [87]. The 4-(substituted-benzylidine)-2-substituted-5,6-dihydrobenzo[h] quinazoline and 4-(substituted benzylidine)-2-substituted-3,4,5,6-tetrahydrobenzo[h] quinazoline from 2-(substituted-benzylidine)tetralone-1 and several substituted guanidine sulfates are evaluated for their in vitro antileishmanial activity and they reported that compounds (100-102) show promising antileishmanial activity against Leishmania donovani [88] (see Scheme 69).

6.13. Quinazoline as Neuroprotective Agents. Few quinazoline derivatives $(\mathbf{1 0 3} \mathbf{a}-\mathbf{c})$ were evaluated for their activity as potent and highly selective PDE5 inhibitors to be employed for male erectile dysfunction [89] (see Scheme 70).

6.14. Quinazoline as Antiobesity Agents. A series of quinazoline derivatives (104-106) are to be considered as an antagonist for melanin concentrating hormone receptor 1 (MCHR1) [90] (see Scheme 71).

6.15. Antihypertensive Agents. A series of 3-benzyl-2substituted-3H-[1,2,4] triazolo[5,1-b]quinazolin-9-ones have been synthesized by the cyclocondensation of 3-amino-2benzylamino-3H-quinazolin-4-one. The compounds were evaluated for their in vivo antihypertensiveactivity. All the test compounds exhibited significant antihypertensive activity; 3 benzyl-2-methyl-3H-[1,2,4] triazolo[5,1-b] quinazolin-9-one exhibited antihypertensive activity more than the reference drug prazocine [91].

6.16. Anti-H $H_{1}$-Antihistaminic Agents. A series of 1-substituted-4-benzyl-4H-[1,2,4] triazolo[4,3-a]quinazolin-5-ones were synthesized by the cyclization of 2-hydrazino-3benzyl-3H-quinazolin-4-one. When tested for their in vivo $\mathrm{H}_{1}$-antihistaminic activity on guinea pigs, all the test 
<smiles>[R]c1cc2c(NCc3ccc(OC)c(Cl)c3)ncnc2c([R])c1[R]</smiles>
103a $\quad \mathrm{C}_{3} \mathrm{H}_{7}$
$\begin{array}{lll}\mathrm{R}_{1} & \mathrm{R}_{2}\end{array}$
103b $\quad \mathrm{CH}_{2} \mathrm{CH}_{2} \mathrm{OH} \quad \mathrm{OCH}_{3} \quad \mathrm{NHCOCH}_{3}$
$\begin{array}{lllll}103 c & \mathrm{CH}_{2} \mathrm{CH}_{2} \mathrm{OH} & \mathrm{OCH}_{3} & \mathrm{NHCOC}_{2} \mathrm{H}_{5}\end{array}$

$(103 a-c)$

SCHEME 70<smiles>CC(=O)CC1(O)CCN(c2nc(C)c3cc(NC(=O)/C=C\c4ccc(Cl)cc4)ccc3n2)CC1</smiles>

SCHEME 71<smiles>[R]C(=O)CCCOc1cc(NCc2ccc3cc(N)cc(N)c3c2)ccc1OC</smiles>

$107 \mathbf{a} \mathrm{R}=-\mathrm{OC}_{2} \mathrm{H}_{5} ; \mathbf{1 0 7} \mathbf{b}=\mathrm{OCH}_{3}$

SCHEME 72

compounds protected the animals from histamine induced bronchospasm significantly [92].

6.17. Quinazoline as Antiprotozoan Agents. A series of quinazoline derivatives (107a-b) were evaluated for their activity as a potent inhibitor of trypanosoma cruzi dihydrofolate reductase [93] (see Scheme 72).

\section{Discussion}

Heterocyclic compound containing quinazoline and quinazolinone nucleus plays most important role in the field of medicinal chemistry. It shows wide range of activities for medication purpose. A large number of quinazoline compounds have been synthesized and evaluated for their different biological activities. Some marketed quinazoline and quinazolinone nucleus containing drugs have different types of pharmacological activities. The quinazoline and quinazolinone based pharmaceuticals are becoming very important class of therapeutic agents and are likely to replace many obtainable organic based pharmaceuticals in the very near future. The quinazoline and quinazolinone based pharmaceuticals will be created on a large scale by different research development processes and will become available commercially for therapeutic uses. The biological profiles of this new generation of quinazoline and quinazolinone represent much progress with regard to the older compounds. This study gets an efficient way of understanding about the target pharmacophore relationship which can further aid the process of drug design developments. This study may also accelerate the designing processes to generate a larger number of therapeutically active molecules. The molecular treatment of potentially lead molecules is still a major line of approaches for the discovery and development of new drug molecules [94-99]. Combination of two or more 
moieties into one is a general procedure of handling and this can probably result in the raise of biological activities and deduction of untoward side effects.

\section{Conclusion}

The various structural modifications around the fused ring of quinazoline and quinazolinone subsequently evaluate are for their usefulness in treating various disease conditions. Quinazoline and quinazolinone, being the central body of the pharmacophore, hold different types of substituent. Based on their various physicochemical properties, they exerted a diversified range of therapeutic efficacy. Thus we can conclude that this review will definitely provide the researchers with a thorough understanding of the structure activity relationship study, which further helps in designing good large number of quinazoline and quinazolinone compounds with a strong impact in curing many fatal disorders.

\section{Conflict of Interests}

The author declares that there is no conflict of interests regarding the publication of this paper.

\section{References}

[1] D. J. Connolly, D. Cusack, T. P. O’Sullivan, and P. J. Guiry, "Synthesis of quinazolinones and quinazolines," Tetrahedron, vol. 61, no. 43, pp. 10153-10202, 2005.

[2] Abida, P. Nayyar, and M. Arpanarana, "An updated review: newer quinazoline derivatives under clinical trial," International Journal of Pharmaceutical \& Biological Archive, vol. 2, no. 6, pp. 1651-1657, 2011.

[3] S. B. Mhaske and N. P. Argade, "The chemistry of recently isolated naturally occurring quinazolinone alkaloids," Tetrahedron, vol. 62, no. 42, pp. 9787-9826, 2006.

[4] A. K. Mahato, B. Srivastava, and S. Nithya, "Chemistry structure activity relationship and biological activity of quinazoline4(3H)-one derivatives," Inventi Rapid: MedChem, vol. 2, no. 1, 2011.

[5] W. L. F. Armarego, A Text Book of Quinazolines, 1963.

[6] R. Rajput and A. P. Mishra, "A review on biological activity of quinazolinones," International Journal of Pharmacy and Pharmaceutical Sciences, vol. 4, no. 2, pp. 66-70, 2012.

[7] B. Pati and S. Banerjee, "Quinazolines: an illustrated review," Journal of Advanced Pharmacy. Education \& Research, vol. 3, no. 3, pp. 136-151, 2013.

[8] B. Vijayakumar, P. Prasanthi, K. M. Teja et al., "Quinazoline derivatives and pharmacological activities: a review," International Journal of Medicinal Chemistry \& Analysis, vol. 3, no. 1, pp. 10-21, 2013.

[9] X. Yang, H. Liu, H. Futa, R. Qiao, Y. Jiang, and Y. Zhao, "Efficient copper-catalyzed synthesis of 4-aminoquinazoline and 2,4-diaminoquinazoline derivatives," Synlett, no. 1, pp. 101106,2010

[10] V. L. Truong and M. Morrow, "Mild and efficient ligand-free copper-catalyzed condensation for the synthesis of quinazolines," Tetrahedron Letters, vol. 51, no. 4, pp. 758-760, 2010.
[11] S. Shweta, S. Chirag, T. Bhawana, and J. Talesara, "Synthesis of phthalimido or succinimido[2-aryl-4-oxo-3-2-phenyl4(3H)-quinazolinon-3-yl-1,3-thiazolidin-5-yl] ethanoate," Journal of the Indian Chemical Society, vol. 86, no. 4, pp. 397-401, 2009.

[12] O. O. Ajani, C. A. Obafemi, C. O. Ikpo, K. O. Ajanaku, K. O. Ogunniran, and O. O. James, "Comparative study of microwave assisted and conventional synthesis of novel 2-quinoxalinone3- hydrazone derivatives and its spectroscopic properties," International Journal of Physical Sciences, vol. 4, no. 4, pp. 156164, 2009.

[13] H. Mutlu and G. Irez, "Synthesis and characterization of new tridentate iminooxime ligands and their Co(III) complexes," Turkish Journal of Chemistry, vol. 32, no. 6, pp. 731-741, 2008.

[14] G. Abdel and H. A. W. Mohammed, "Design and synthesis of some new derivatives of $3 \mathrm{H}$-quinazolin-4-one with promising anticonvulsant activity," Acta Pharmaceutica, vol. 53, no. 2, pp. 127-138, 2003.

[15] A.-F. E. Mourad, A. A. Aly, H. H. Farag, and E. A. Beshr, "Microwave assisted synthesis of triazoloquinazolinones and benzimidazoquinazolinones," Beilstein Journal of Organic Chemistry, vol. 3, article 11, 2007.

[16] N. M. Abdel Gawad, H. H. Georgey, R. M. Youssef, and N. A. El-Sayed, "Synthesis and antitumor activity of some 2, 3disubstituted quinazolin-4(3H)-ones and 4, 6- disubstituted1, 2, 3, 4-tetrahydroquinazolin-2H-ones," European Journal of Medicinal Chemistry, vol. 45, no. 12, pp. 6058-6067, 2010.

[17] J. He, X. Wang, X. Zhao, Y. Liang, H. He, and L. Fu, "Synthesis and antitumor activity of novel quinazoline derivatives containing thiosemicarbazide moiety," European Journal of Medicinal Chemistry, vol. 54, pp. 925-930, 2012.

[18] B. Marvania, P.-C. Lee, R. Chaniyara et al., "Design, synthesis and antitumor evaluation of phenyl $\mathrm{N}$-mustard-quinazoline conjugates," Bioorganic and Medicinal Chemistry, vol. 19, no. 6, pp. 1987-1998, 2011.

[19] H.-Q. Li, D.-D. Li, X. Lu, Y.-Y. Xu, and H.-L. Zhu, "Design and synthesis of 4,6-substituted-(diaphenylamino)quinazolines as potent EGFR inhibitors with antitumor activity," Bioorganic and Medicinal Chemistry, vol. 20, no. 1, pp. 317-323, 2012.

[20] C. Fernandes, C. Oliveira, L. Gano, A. Bourkoula, I. Pirmettis, and I. Santos, "Radioiodination of new EGFR inhibitors as potential SPECT agents for molecular imaging of breast cancer," Bioorganic and Medicinal Chemistry, vol. 15, no. 12, pp. 39743980, 2007.

[21] K. G. Petrov, Y.-M. Zhang, M. Carter et al., "Optimization and SAR for dual ErbB-1/ErbB-2 tyrosine kinase inhibition in the 6furanylquinazoline series," Bioorganic and Medicinal Chemistry Letters, vol. 16, no. 17, pp. 4686-4691, 2006.

[22] A. S. Rosenthal, C. Tanega, M. Shen et al., "Potent and selective small molecule inhibitors of specific isoforms of Cdc2-like kinases (Clk) and dual specificity tyrosine-phosphorylationregulated kinases (Dyrk)," Bioorganic and Medicinal Chemistry Letters, vol. 21, no. 10, pp. 3152-3158, 2011.

[23] F. Gellibert, M. H. Fouchet, V. L. Nguyen et al., "Design of novel quinazoline derivatives and related analogues as potent and selective ALK5 inhibitors," Bioorganic and Medicinal Chemistry Letters, vol. 19, no. 8, pp. 2277-2281, 2009.

[24] A. Wissner, H. L. Fraser, C. L. Ingalls et al., "Dual irreversible kinase inhibitors: quinazoline-based inhibitors incorporating two independent reactive centers with each targeting different 
cysteine residues in the kinase domains of EGFR and VEGFR2," Bioorganic and Medicinal Chemistry, vol. 15, no. 11, pp. 36353648, 2007.

[25] M. N. Noolvi and H. M. Patel, "A comparative QSAR analysis and molecular docking studies of quinazoline derivatives as tyrosine kinase (EGFR) inhibitors: a rational approach to anticancer drug design," Journal of Saudi Chemical Society, vol. 17, no. 4, pp. 361-379, 2013.

[26] J. A. Heath, M. M. Mehrotra, S. Chi et al., "Identification of 4-piperazin-1-yl-quinazoline template based aryl and benzyl thioureas as potent, selective, and orally bioavailable inhibitors of platelet-derived growth factor (PDGF) receptor," Bioorganic and Medicinal Chemistry Letters, vol. 14, no. 19, pp. 4867-4872, 2004.

[27] K. Matsuno, T. Seishi, T. Nakajima et al., "Potent and selective inhibitors of platelet-derived growth factor receptor phosphorylation, part 4: structure-activity relationships for substituents on the quinazoline moiety of 4-[4-(N-substituted(thio)carbamoyl)-1-piperazinyl]-6,7-dimethoxyquinazoline derivatives," Bioorganic and Medicinal Chemistry Letters, vol. 13, no. 18, pp. 3001-3004, 2003.

[28] N. M. Heron, M. Anderson, D. P. Blowers et al., "SAR and inhibitor complex structure determination of a novel class of potent and specific Aurora kinase inhibitors," Bioorganic and Medicinal Chemistry Letters, vol. 16, no. 5, pp. 1320-1323, 2006.

[29] K. M. Foote, A. A. Mortlock, N. M. Heron et al., "Synthesis and SAR of 1-acetanilide-4-aminopyrazole-substituted quinazolines: Selective inhibitors of Aurora B kinase with potent antitumor activity," Bioorganic and Medicinal Chemistry Letters, vol. 18, no. 6, pp. 1904-1909, 2008.

[30] Z. Chen, X. Huang, H. Yang et al., "Anti-tumor effects of B-2, a novel 2,3-disubstituted 8-arylamino-3H-imidazo[4,5g]quinazoline derivative, on the human lung adenocarcinoma A549 cell line in vitro and in vivo," Chemico-Biological Interactions, vol. 189, no. 1-2, pp. 90-99, 2011.

[31] P. Ballard, R. H. Bradbury, C. S. Harris et al., "Inhibitors of epidermal growth factor receptor tyrosine kinase: Novel C-5 substituted anilinoquinazolines designed to target the ribose pocket," Bioorganic and Medicinal Chemistry Letters, vol. 16, no. 6, pp. 1633-1637, 2006.

[32] P. M. Chandrika, T. Yakaiah, A. R. R. Rao et al., "Synthesis of novel 4,6-disubstituted quinazoline derivatives, their antiinflammatory and anti-cancer activity (cytotoxic) against U937 leukemia cell lines," European Journal of Medicinal Chemistry, vol. 43 , no. 4 , pp. 846-852, 2008.

[33] L. Zhu, J. Jin, C. Liu et al., "Synthesis and biological evaluation of novel quinazoline-derived human Pin1 inhibitors," Bioorganic and Medicinal Chemistry, vol. 19, no. 9, pp. 2797-2807, 2011.

[34] A. S. El-Azab, M. A. Al-Omar, A. A. M. Abdel-Aziz et al., "Design, synthesis and biological evaluation of novel quinazoline derivatives as potential antitumor agents: Molecular docking study," European Journal of Medicinal Chemistry, vol. 45, no. 9, pp. 4188-4198, 2010.

[35] L. Cedric, T. Alexandra, T. Valerie et al., "Synthesis, biological evaluation and molecular modeling studies of quinazoline derivatives," European Journal of Medicinal Chemistry, vol. 43, pp. 1469-1477, 2008.

[36] P. Selvam, P. Vijayalakshimi, D. F. Smee et al., "Novel 3sulphonamido-quinazolin-4(3H)-one derivatives: Microwaveassisted synthesis and evaluation of antiviral activities against respiratory and biodefense viruses," Antiviral Chemistry and Chemotherapy, vol. 18, no. 5, pp. 301-305, 2007.
[37] G. D. Galarce, R. E. Foncea, A. M. Edwards, H. PessoaMahana, C. D. Pessoa-Mahana, and R. A. Ebensperger, "Biological evaluation of novel 6-Arylbenzimidazo [1,2-c]quinazoline derivatives as inhibitors of LPS-induced TNF-alpha secretion," Biological Research, vol. 41, no. 1, pp. 43-50, 2008.

[38] K. S. Hatti, V. Chandregowda, G. Venkateswara Rao, A. Kush, and G. Chandrasekara Reddy, "In-silico interaction studies of quinazoline derivatives for their inhibitory action on both wild and mutant EGFRs," Journal of Proteomics and Bioinformatics, vol. 2, no. 3, pp. 126-130, 2009.

[39] D. Raffa, G. Daidone, B. Maggio, S. Cascioferro, F. Plescia, and D. Schillaci, "Synthesis and antileukemic activity of new 3-(5-methylisoxazol-3-yl) and 3-(pyrimidin-2-yl)-2styrylquinazolin-4(3H)-ones," Farmaco, vol. 59, no. 6, pp. 451455, 2004.

[40] N. B. Patel and J. C. Patel, "Synthesis and antimicrobial activity of Schiff bases and 2-azetidinones derived from quinazolin4(3H)-one," Arabian Journal of Chemistry, vol. 4, no. 4, pp. 403411, 2011.

[41] M. Cakici, M. Catir, S. Karabuga et al., "Synthesis and biological evaluation of (S)-4-aminoquinazoline alcohols," Tetrahedron Asymmetry, vol. 21, no. 16, pp. 2027-2031, 2010.

[42] P. M. S. Bedi, V. Kumar, and M. P. Mahajan, "Synthesis and biological activity of novel antibacterial quinazolines," Bioorganic and Medicinal Chemistry Letters, vol. 14, no. 20, pp. 5211-5213, 2004.

[43] A. M. Alafeefy, A. S. El-Azab, M. A. Mohamed, M. A. Bakhat, and S. G. Abdel-Hamid, "Synthesis of some new substituted iodoquinazoline derivatives and their antimicrobial screening," Journal of Saudi Chemical Society, vol. 15, no. 4, pp. 319-325, 2011.

[44] V. Jatav, S. Kashaw, and P. Mishra, "Synthesis, antibacterial and antifungal activity of some novel 3-[5-(4-substituted phenyl) 1,3,4-thiadiazole-2-yl]-2-styryl quinazoline-4(3H)-ones," $M e$ dicinal Chemistry Research, vol. 17, no. 2-7, pp. 169-181, 2008.

[45] P. Praveen Kumar, Y. Rajendra Prasad, N. R. Kumar, and S. Sridhar, "Synthesis and antimicrobial activity of 6,7,8,9tetrahydro-5(H)-5-nitrophenylthiazolo [2,3-b]-quinazoline$3(2 \mathrm{H})$-one derivatives," Asian Journal of Chemistry, vol. 20, no. 7, pp. 5161-5165, 2008.

[46] K. Siddappa, T. Reddy, M. Mallikarjun, and C. V. Reddy, "Synthesis, characterization and antimicrobial studies of 3-[(2-hydroxy-quinolin-3-ylmethylene)-amino]-2-phenyl-3Hquinazolin-4-one and its metal(II) complexes," E-Journal of Chemistry, vol. 5, no. 1, pp. 155-162, 2008.

[47] N. C. Desai, P. N. Shihora, and D. L. Moradia, "Synthesis and characterization of new quinazolines as potential antimicrobial agents," Indian Journal of Chemistry, vol. 46, no. 3, pp. 550-553, 2007.

[48] R. Suthakaran, S. Kavimani, P. Venkaiaiah, and K. Suganthi, "Synthesis and antimicrobial activity of 3-(2-(4z)-4-substituted benzylidene-4,5-dihydro-5-oxo-2-phenylimidazol-1-yl)ethyl)6,8-un/dibromo subtituted-2-substituted quinazoline- $(3 H)$ one," Rasāyan Journal of Chemistry, vol. 1, no. 1, pp. 22-29, 2008.

[49] S. Jantová, Š. Stankovský, and K. Špirková, “In vitro antibacterial activity of ten series of substituted quinazolines," Biologia, vol. 59, no. 6, pp. 741-752, 2004.

[50] J. A. Patel, B. D. Mistry, and K. R. Desai, "Synthesis and antimicrobial activity of newer quinazolinones," E-Journal of Chemistry, vol. 3, no. 2, pp. 97-102, 2006. 
[51] M. M. Ghorab, S. M. Abdel-Gawad, and M. S. A. El-Gaby, "Synthesis and evaluation of some new fluorinated hydroquinazoline derivatives as antifungal agents," Farmaco, vol. 55, no. 4, pp. 249-255, 2000.

[52] G.-F. Xu, B.-A. Song, P. S. Bhadury et al., "Synthesis and antifungal activity of novel s-substituted 6-fluoro4-alkyl(aryl)thioquinazoline derivatives," Bioorganic and Medicinal Chemistry, vol. 15, no. 11, pp. 3768-3774, 2007.

[53] A. Omar and M. A. Ahmed, "Synthesis of some new $3 \mathrm{H}$-quinazolin-4-one derivatives as potential Antitubercular agents," World Applied Sciences Journal, vol. 5, no. 1, pp. 94-99, 2008.

[54] J. Í Kune, B. Jaroslav, M. Pour, K. Waisser, M. Iosárek, and J. Í Janota, "Quinazoline derivatives with antitubercular activity," Farmaco, vol. 55, no. 11-12, pp. 725-729, 2000.

[55] V. K. Srivastava and A. Kumar, "Synthesis of newer thiadiazolyl and thiazolidinonyl quinazolin- $4(3 \mathrm{H})$-ones as potential anticonvulsant agents," European Journal of Medicinal Chemistry, vol. 37, no. 11, pp. 873-882, 2003.

[56] P. Kumar, K. N. Dhawan, S. Vrat, K. P. Bhargava, and K. Kishore, "Synthesis of 6-substituted 2-phenyl-3-(5-substituted mercapto-1,3,4,thiadiazol-2-yl)quinazolin-4-(3H)-ones as antitubercular agents," Archiv der Pharmazie, vol. 316, no. 9, pp. 759$763,1983$.

[57] K. S. Kumar, S. Ganguly, R. Veerasamy, and E. De Clercq, "Synthesis, antiviral activity and cytotoxicity evaluation of Schiff bases of some 2-phenyl quinazoline-4(3)H-ones," European Journal of Medicinal Chemistry, vol. 45, no. 11, pp. 5474-5479, 2010.

[58] M. Schleiss, J. Eickhoff, S. Auerochs et al., "Protein kinase inhibitors of the quinazoline class exert anti-cytomegaloviral activity in vitro and in vivo," Antiviral Research, vol. 79, no. 1 , pp. 49-61, 2008.

[59] S. N. Pandeya, D. Sriram, G. Nath, and E. de Clercq, "Synthesis, antibacterial, antifungal and anti-HIV evaluation of Schiff and Mannich bases of isatin derivatives with 3-amino2-methylmercapto quinazolin-4(3H)-one," Pharmaceutica Acta Helvetiae, vol. 74, no. 1, pp. 11-17, 1999.

[60] D. Kohli, S. R. Hashim, S. Vishal, M. Sharma, and A. K. Singh, "Synthesis and antibacterial activity of quinazolinone derivatives," International Journal of Pharmacy and Pharmaceutical Sciences, vol. 1, no. 1, pp. 163-169, 2009.

[61] C. Ye, J. You, X. F. Li et al., "Design, synthesis and anticoccidial activity of a series of 3-(2-(2-methoxyphenyl)-2-oxoethyl) quinazolinone derivatives," Pesticide Biochemistry and Physiology, vol. 97, no. 3, pp. 194-198, 2010.

[62] J. You, C. Ye, Y. Weng, X. Mo, and Y. Wang, "Synthesis and anticoccidial activity of 4-(2-methoxyphenyl)-2- oxobutylquinazolinone derivatives," Arkivoc, vol. 2008, no. 17, pp. 1-11, 2008.

[63] A. M. Alafeefy, A. A. Kadi, O. A. Al-Deeb, K. E. H. El-Tahir, and N. A. Al-Jaber, "Synthesis, analgesic and anti-inflammatory evaluation of some novel quinazoline derivatives," European Journal of Medicinal Chemistry, vol. 45, no. 11, pp. 4947-4952, 2010.

[64] R. S. Giri, H. M. Thaker, T. Giordano et al., "Design, synthesis and characterization of novel 2-(2,4-disubstituted-thiazole-5yl)-3-aryl-3H-quinazoline-4-one derivatives as inhibitors of NF- $\kappa \mathrm{B}$ and AP-1 mediated transcription activation and as potential anti-inflammatory agents," European Journal of Medicinal Chemistry, vol. 44, no. 5, pp. 2184-2189, 2009.
[65] V. Alagarsamy, V. Raja Solomon, and K. Dhanabal, "Synthesis and pharmacological evaluation of some 3phenyl-2-substituted-3H-quinazolin-4-one as analgesic, antiinflammatory agents," Bioorganic and Medicinal Chemistry, vol. 15, no. 1, pp. 235-241, 2007.

[66] K. Hemalatha and K. Girija, "Synthesis of some novel 2, 3disubstituted quinazolinone derivatives as analgesic and antiinflammatory agents," International Journal of Pharmacy and Pharmaceutical Sciences, vol. 3, no. 2, pp. 103-106, 2011.

[67] A. Kumar, S. Sharma, K. Bajaj et al., "Some new 2,3,6trisubstituted quinazolinones as potent anti-inflammatory, analgesic and COX-II inhibitors," Bioorganic and Medicinal Chemistry, vol. 11, no. 23, pp. 5293-5299, 2003.

[68] C. Balakumar, P. Lamba, D. Pran Kishore et al., "Synthesis, anti-inflammatory evaluation and docking studies of some new fluorinated fused quinazolines," European Journal of Medicinal Chemistry, vol. 45, no. 11, pp. 4904-4913, 2010.

[69] S. M. Mosaad, K. I. Mohamed, M. A. Ahmed, G. A. Sami, and M. M. Adel, "Synthesis and anti-inflammatory evaluation of some quinazoline derivatives," International Journal of Pharmacology, vol. 1, no. 3, pp. 261-266, 2005.

[70] C. H. Rajver, C. H. Swarnalatha, R. Stephen, and Sudharshini, "Synthesis of 6-bromo-oxo quinazoline derivatives and their pharmacological activities," International Journal of Chemical Research, vol. 1, no. 1, pp. 21-24, 2010.

[71] M. Srivastav and S. M. Shantakumar, "Synthesis and Antiinflammatory activity of some novel 3-(6-substituted-1,3benzothiazole-2-yl)-2-[(4-substituted phenyl) amino methyl] quinazolines-4 (3H)-ones," E-Journal of Chemistry, vol. 6, no. 4, pp. 1055-1062, 2009.

[72] A. Omar, M. F. Fattah, M. M. Emad, M. I. Neama, and M. K. Mohsen, "Synthesis of some new quinazolin-4-one derivatives and evaluation of their antimicrobial and antiinflammatory effects," Acta Poloniae Pharmaceutica: Drug Research, vol. 65, no. 1, pp. 11-20, 2008.

[73] V. Jatav, P. Mishra, S. Kashaw, and J. P. Stables, "Synthesis and CNS depressant activity of some novel 3-[5-substituted 1,3,4thiadiazole-2-yl]-2-styryl quinazoline-4(3H)-ones," European Journal of Medicinal Chemistry, vol. 43, no. 1, pp. 135-141, 2008.

[74] V. Jatav, P. Mishra, S. Kashaw, and J. P. Stables, "CNS depressant and anticonvulsant activities of some novel 3-[5-substituted 1,3,4-thiadiazole-2-yl]-2-styryl quinazoline-4(3H)-ones," European Journal of Medicinal Chemistry, vol. 43, no. 9, pp. 19451954, 2008.

[75] M. M. Aly, Y. A. Mohamed, K. A. M. El-Bayouki, W. M. Basyouni, and S. Y. Abbas, "Synthesis of some new 4(3H)quinazolinone-2-carboxaldehyde thiosemicarbazones and their metal complexes and a study on their anticonvulsant, analgesic, cytotoxic and antimicrobial activities," European Journal of Medicinal Chemistry, vol. 45, no. 8, pp. 3365-3373, 2010.

[76] S. K. Kashaw, V. Kashaw, P. Mishra, N. K. Jain, and J. P. Stables, "Synthesis, anticonvulsant and CNS depressant activity of some new bioactive 1-(4-substituted-phenyl)-3-(4-oxo-2phenyl/ethyl-4H-quinazolin-3-yl)-urea," European Journal of Medicinal Chemistry, vol. 44, no. 11, pp. 4335-4343, 2009.

[77] A. Gürsoy and N. Terzioğlu, "Synthesis and isolation of new regioisomeric 4-thiazolidinones and their anticonvulsant activity," Turkish Journal of Chemistry, vol. 29, no. 3, pp. 247-254, 2005.

[78] V. K. Pandey, S. Tusi, Z. Tusi et al., “Thiadiazolyl quinazolones as potential antiviral and antihypertensive agents," Indian Journal 
of Chemistry Section B: Organic and Medicinal Chemistry, vol. 43, no. 1, pp. 180-183, 2004.

[79] V. K. Srivastava and A. Kumar, "Synthesis of some newer derivatives of substituted quinazolinonyl-2-oxo/thiobarbituric acid as potent anticonvulsant agents," Bioorganic and Medicinal Chemistry, vol. 12, no. 5, pp. 1257-1264, 2004.

[80] R. Chioua, F. Benabdelouahab, M. Chioua, R. Martínez-Alvarez, and A. Herrera Fernández, "Synthesis of novel quinazoline derivatives via pyrimidine ortho-quinodimethane," Molecules, vol. 7, no. 7, pp. 507-510, 2002.

[81] L. M. Werbel and M. J. Degnan, "Synthesis and antimalarial and antitumor effects of 2-amino-4-(hydrazino and hydroxyamino)-6-[(aryl)thio]quinazolines," Journal of Medicinal Chemistry, vol. 30, no. 11, pp. 2151-2154, 1987.

[82] Y. Kabri, N. Azas, A. Dumètre et al., "Original quinazoline derivatives displaying antiplasmodial properties," European Journal of Medicinal Chemistry, vol. 45, no. 2, pp. 616-622, 2010.

[83] S. Madapa, Z. Tusi, A. Mishra et al., "Search for new pharmacophores for antimalarial activity. Part II. Synthesis and antimalarial activity of new 6-ureido-4-anilinoquinazolines," Bioorganic and Medicinal Chemistry, vol. 17, no. 1, pp. 222-234, 2009.

[84] P. Verhaeghe, A. Dumtre, C. Castera-Ducros et al., "4Thiophenoxy-2-trichloromethyquinazolines display in vitro selective antiplasmodial activity against the human malaria parasite Plasmodium falciparum," Bioorganic and Medicinal Chemistry Letters, vol. 21, no. 19, pp. 6003-6006, 2011.

[85] P. Verhaeghe, N. Azas, M. Gasquet et al., "Synthesis and antiplasmodial activity of new 4-aryl-2-trichloromethylquinazolines," Bioorganic and Medicinal Chemistry Letters, vol. 18, no. 1, pp. 396-401, 2008.

[86] T. P. Selvam, P. V. Kumar, and A. S. Kumar, "Synthesis and anti-oxidant activity of novel 6,7,8,9 tetra hydro- $5 \mathrm{H}$ 5-(2'-hydroxy phenyl)-2-(4'-substituted benzylidine)- 3-(4nitrophenyl amino) thiazolo quinazoline derivatives," Research in Biotechnology, vol. 1, no. 1, pp. 38-48, 2010.

[87] W. L. Armarego, The Chemistry of Heterocyclic Compound Fused Pyrimidines, vol. 11, part-1, 1967.

[88] K. C. Agarwal, V. Sharma, N. Shakya, and S. Gupta, "Design and synthesis of novel substituted quinazoline derivatives as antileishmanial agents," Bioorganic and Medicinal Chemistry Letters, vol. 19, no. 18, pp. 5474-5477, 2009.

[89] Y. H. Kim, H. Choi, J. Lee et al., "Quinazolines as potent and highly selective PDE5 inhibitors as potential therapeutics for male erectile dysfunction," Bioorganic and Medicinal Chemistry Letters, vol. 18, no. 23, pp. 6279-6282, 2008.

[90] S. Sasmal, D. Balasubrahmanyam, H. R. Kanna Reddy et al., "Design and optimization of quinazoline derivatives as melanin concentrating hormone receptor 1 (MCHR1) antagonists: part 2," Bioorganic and Medicinal Chemistry Letters, vol. 22, no. 9, pp. 3163-3167, 2012.

[91] V. Alagarsamy and U. S. Pathak, "Synthesis and antihypertensive activity of novel 3-benzyl-2-substituted-3H-[1,2,4] triazolo[5,1b]quinazolin-9-ones," Bioorganic and Medicinal Chemistry, vol. 15, no. 10, pp. 3457-3462, 2007.

[92] V. Alagarsamy, V. R. Solomon, and M. Murugan, "Synthesis and pharmacological investigation of novel 4-benzyl-1-substituted$4 \mathrm{H}$-[1,2,4] triazolo[4,3-a]quinazolin-5-ones as new class of $\mathrm{H1}$ antihistaminic agents," Bioorganic and Medicinal Chemistry, vol. 15, no. 12, pp. 4009-4015, 2007.

[93] N. Schormann, S. E. Velu, S. Murugesan et al., "Synthesis and characterization of potent inhibitors of Trypanosoma cruzi dihydrofolate reductase," Bioorganic and Medicinal Chemistry, vol. 18, no. 11, pp. 4056-4066, 2010.

[94] J. P. Patil, S. V. Amrutkar, and M. S. Ranawat, "Microwave assisted synthesis of quinazolinone using different bases," Journal of Pharmaceutical Sciences and Research, vol. 1, no. 3, pp. 52-54, 2009.

[95] E. Georgescu, F. Georgescu, M. R. Caira et al., "A new synthesis of pyrrolo[1,2-c] quinazoline from quinazolinium N-ylides: a reinvestigation," Arkivoc, vol. 2009, no. 12, pp. 232-241, 2009.

[96] Z. Rachid, M. MacPhee, C. Williams, M. Todorova, and B. J. Jean-Claude, "Design and synthesis of new stabilized combitriazenes for targeting solid tumors expressing the epidermal growth factor receptor (EGFR) or its closest homologue HER2," Bioorganic and Medicinal Chemistry Letters, vol. 19, no. 18, pp. 5505-5509, 2009.

[97] S. H. Yang, D. B. Khadka, S. H. Cho et al., "Virtual screening and synthesis of quinazolines as novel JAK2 inhibitors," Bioorganic and Medicinal Chemistry, vol. 19, no. 2, pp. 968-977, 2011.

[98] D. Kohli, S. R. Hashim, S. Vishal, M. Sharma, and A. K. Singh, "Synthesis and antibacterial activity of quinazolinone derivatives," International Journal of Pharmacy and Pharmaceutical Sciences, vol. 1, pp. 163-169, 2009.

[99] I. P. Jung, H. L. So, S. C. Chan, and S. K. Kwan, "Study on the selective reduction of $1 \mathrm{H}$-quinazoline-2,4-diones," Bulletin of the Korean Chemical Society, vol. 29, no. 6, pp. 1256-1258, 2008. 

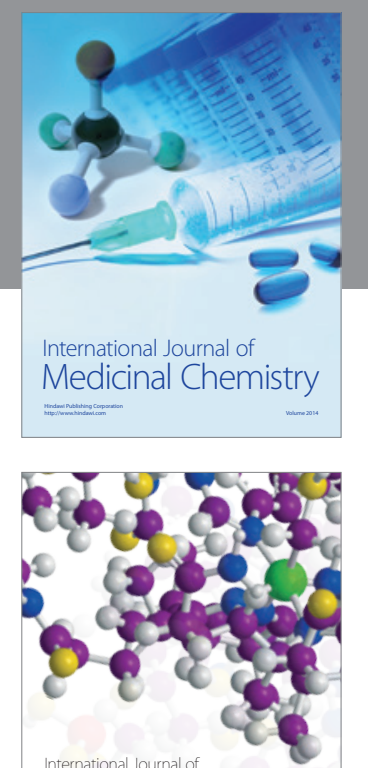

\section{Carbohydrate} Chemistry

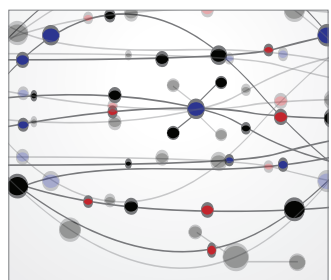

The Scientific World Journal
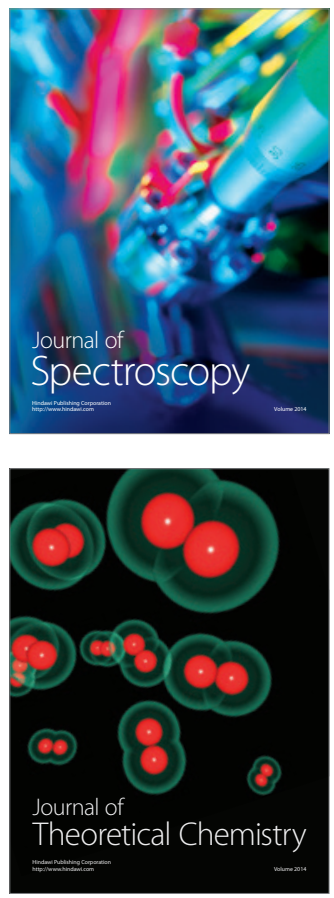
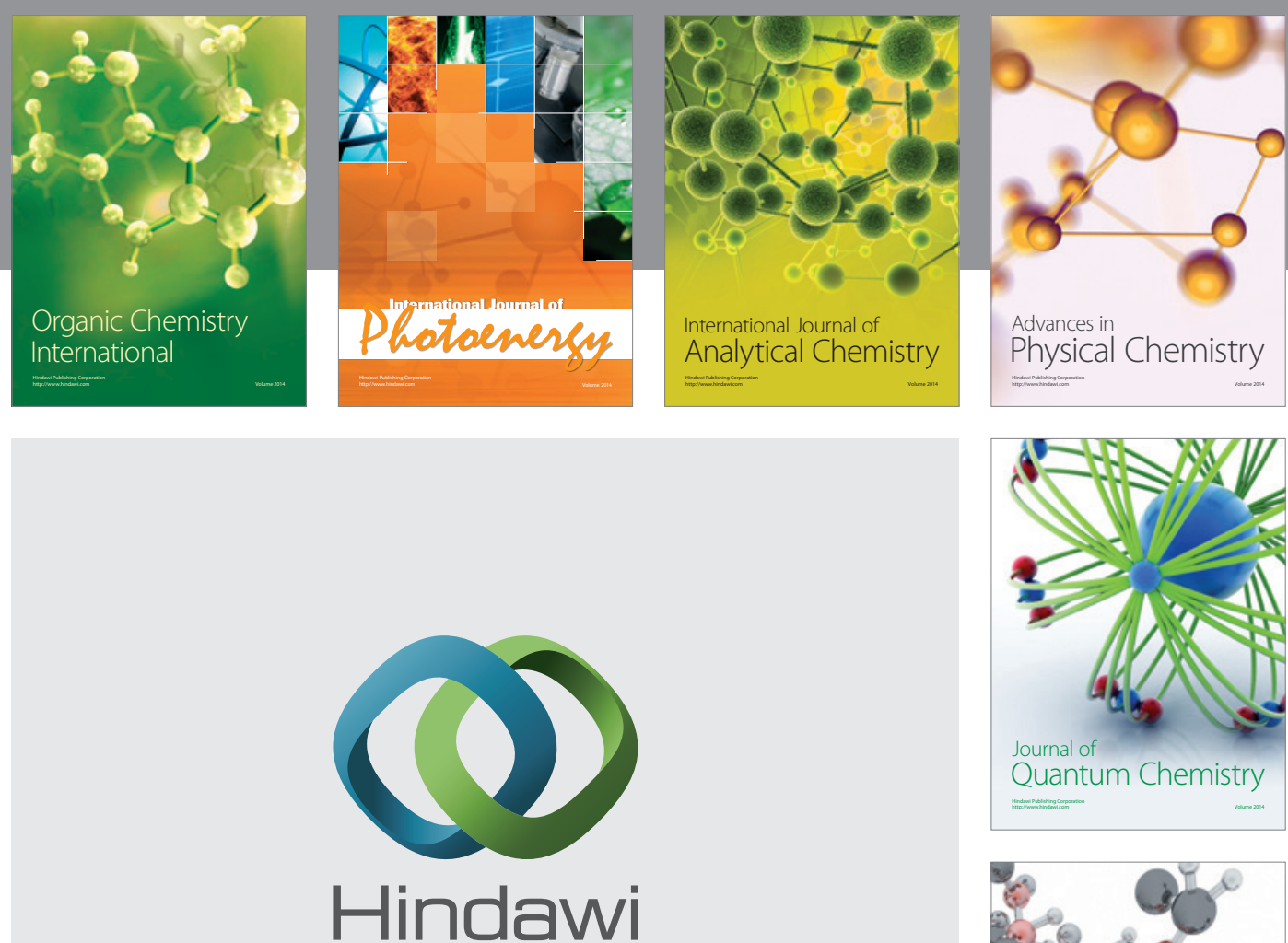

Submit your manuscripts at

http://www.hindawi.com

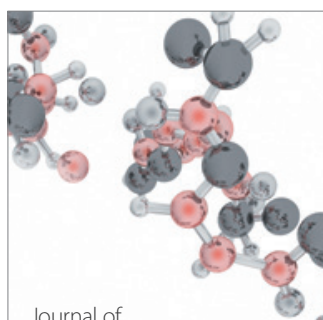

Analytical Methods

in Chemistry

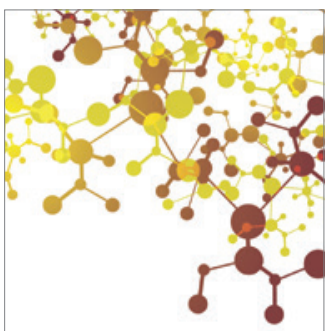

Journal of

Applied Chemistry

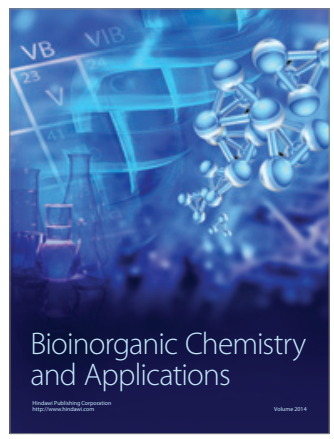

Inorganic Chemistry
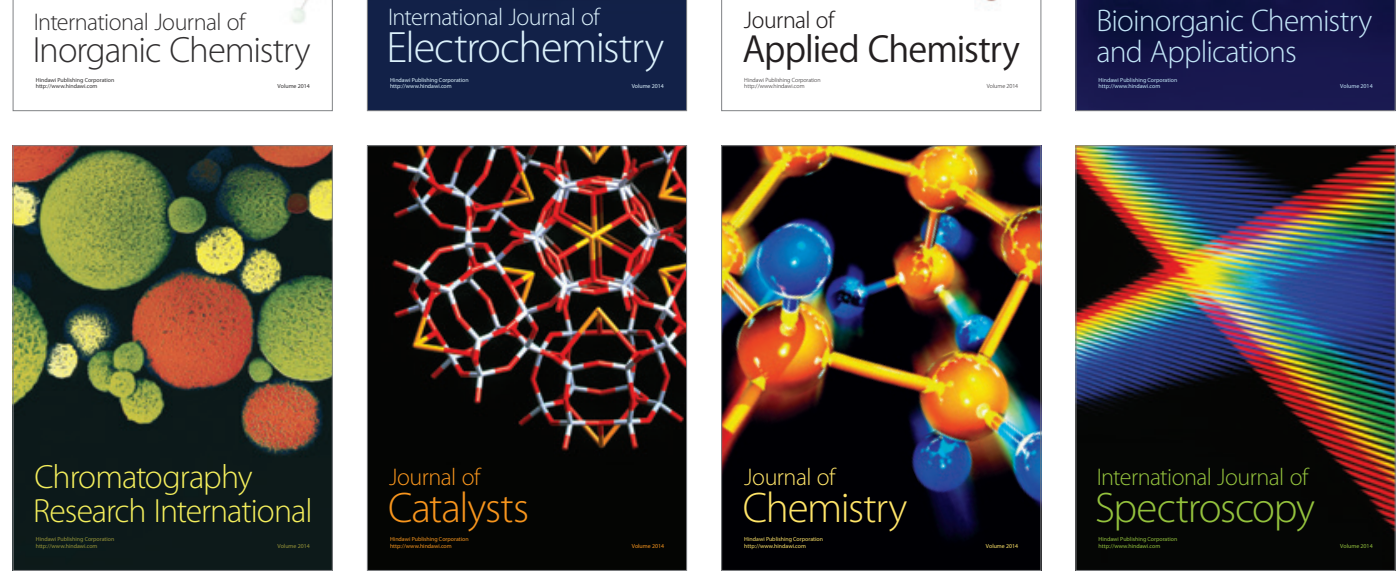